\title{
Plant Products in the Treatment and Control of Filariasis and Other Helminth Infections and Assay Systems for Antifilarial/Anthelmintic Activity
}

Authors

Affiliations
Puvvada Kalpana Murthy ${ }^{1}$, Sujith Kurian Joseph ${ }^{1}$, Puvvada Sri Ramchandra Murthy ${ }^{2}$

${ }^{1}$ Division of Parasitology, Central Drug Research Institute, CSIR, Lucknow, India

${ }^{2}$ Division of Toxicology, Central Drug Research Institute, CSIR, Lucknow, India
Key words

plant products

- filariasis

- helminthiasis

0 in vitro assays

0 in vivo assays received May 30, 2010

revised Sept. 5, 2010

accepted Sept. 23, 2010

\section{Bibliography}

Dol http://dx.doi.org/ 10.1055/s-0030-1250452

Published online October 18, 2010

Planta Med 2011; 77: 647-661

(c) Georg Thieme Verlag KG

Stuttgart · New York .

ISSN 0032-0943

\section{Correspondence}

Dr. Puvvada Kalpana Murthy

Division of Parasitology

Central Drug Research Institute,

CSIR, MG Marg

Lucknow 226001

India

Phone: + 91522261241218 ;

Extn: 4427

Fax: + 915222623405 ;

2623938; 2629504

drpkmurthy@yahoo.com

\section{Abstract}

$\nabla$

Lymphatic filariasis, onchocerciasis, loaisis, and other helminth infections cause serious health problems especially in resource-limited tropical and subtropical developing countries of the world, and more than 2 billion people are infected with at least one helminth species. From times immemorial, man looked up to the plant kingdom in search of anthelmintics, antifilarials, and remedies for parasite-induced health problems. Although more than $50 \%$ of drugs in modern

\section{Introduction}

$\nabla$

Since the time man first discovered the plant kingdom as a rich and convenient source of food, he returned to this kingdom repeatedly and found there remedies for illness too. As a result, several knowledge bases of how to treat or prevent illness and diseases using plants were generated. Some of this knowledge was passed on through generations by "word" ("folk medicine") and some was compiled and practiced, such as Ayurveda in India, Kampo and traditional Chinese medicine (TCM) in Japan, Taiwan, and China. Today, about $50 \%$ of the drugs used in modern medicine are of plant origin [1] and the success stories include the mito-inhibitor vinca alkaloids vincristine \& vinblastin (from Vinca rosea) and their semisynthetic analogues vinorelbine and vindesine as anticancer agents, the topoisomerase II inhibitors etoposide and teniposide which are semisynthetic isomers of the cytotoxic podophyllotoxin from Podophyllum spp., the taxanes and camptothecins, also anticancer agents [2], and the antimalarial artemesinin and its derivatives from Artemesia annua [3]. However, there are very few success stories related to antifilarial or anthelmintic activity, with the possible exception of ivermectin which is a macrocyclic lactone derived from medicine are derived from plants or leads from plants, a success story of plant-based anthelminthics or antifilarials is yet to be told. In the last 5 decades, more than 100 plant products were reported to be beneficial in the treatment or control of these parasitic infections but they could not be developed into viable drugs for a variety of reasons. This review focuses on the plant products reported to be useful in the control and treatment of human helminth infections with the main emphasis on filariasis and the in vitro and in vivo systems available for assaying anthelmintic activity.

Streptomyces avermitilis. This review focuses on the plant products reported to show activity against human helminth parasitic infections with the main emphasis on filarial infections and the in vitro and in vivo systems employed to assay the (antifilarial) activity.

\section{The Parasites}

$\nabla$

The helminth parasites represent an extreme in the spectrum of pathogens as they are probably the only multicellular pathogens infecting man and animals. The helminth parasites comprise two very distantly related taxa: (1) the round worms or nematodes belonging to Nemathelminthes (Class: Nematoda); and (2) the flatworms or Platyhelminthes (Class: Cestoda and Trematoda).

Worldwide, more than 2 billion people are infected with at least one helminth species [4]. The majority of these infections occur in resourcelimited tropical and subtropical developing countries of the world, where over half of the population may harbor infections [5]. Of the various helminthic infections in man, those caused by filarial parasites are particularly important because of the huge loss of man-hours they cause. 
The filarial parasites (Class: Nematoda; Superfamily: Filarioidea) include approximately 500 species infecting almost all vertebrates except fish. The parasites reside in lymphatics, connective tissues, or body cavities of the vertebrate hosts, and the infection is transmitted by a blood-sucking arthropod vector.

The filarial species infecting only humans are: Wuchereria brancrofti, Brugia malayi, and B. timori, which are responsible for lymphatic filariasis (LF) causing debilitating disease manifestations such as "elephantiasis" and hydrocele, Onchocerca volvulus that causes "river blindness", and Loa loa causing "loiasis" ("calabar swelling"). Other prevalent but benign human filariids are: Acanthocheilonema perstans, Acanthocheilonema streptocerca, and Mansonella ozzardi, as well as the less frequent minor species: $W$. lewisi, B. beaveri, B. guyanensis, $M$. semiclarum, Dipetalonema arbuta, D. sprenti, Microfilaria bolivarensis, and M. rodhaini.

LF is a major disease with ever increasing prevalence in the developing world and the second leading cause of permanent and long-term disability. Globally, about 1 billion people live in areas endemic to LF ( 80 countries) and thus are exposed to the risk of infection. About 120 million suffer from the infection or the chronic filarial disease manifestations such as edema of limbs, breast, external genitalia, or hydrocele [6].

It is estimated that medical treatment for acute and chronic LF manifestations costs millions of dollars each year across the endemic regions. In India alone over 10 million people per year seek treatment for LF, which accounts for a total of 30 million dollars per annum. It is thought that the measurable health care costs of treating LF are small in proportion to the individual and societal costs from lost productivity. The contribution of LF to tropical disease burden in terms of disability adjusted life years (DALY) which basically indicates the amount of healthy life expectancy lost because of a disease or disability caused by it, or risk factor, including both mortality and morbidity - is around 5.94 million globally and over 2.62 million for India [7].

LF infection is spread by Anopheles, Culex, Aedes, and Mansonia species of mosquitoes. During a blood meal, the mosquito takes up the stage 1 larvae or microfilariae ( $\mathrm{mf}$ ) circulating in the blood of an infected human. In the mosquito, mf undergoes two molts to become stage 3 infective larvae $\left(\mathrm{L}_{3}\right)$ which enter the human host during a blood meal of the vector. $\mathrm{L}_{3}$ penetrate through the local connective tissue and enter the lymphatic vessels [8] where they take 2 to 12 months to develop into adult worms through two molts. Mature male and female worms mate and produce the progeny, mf, which enter the bloodstream from where they are picked up by the mosquito during its blood meal, and the life cycle continues.

Onchocerciasis is the second major filarial disease group and affects around 18 million people, mainly in tropical Africa and Latin America [9]. The infection is presented as a spectrum of dermal and ocular lesions resulting from the presence of microfilariae in the skin and eyes. The severity of the pathology which may cause blindness has attracted a massive international effort to reduce the impact of onchocerciasis through vector control and by mass chemotherapy [10].

Among non-filarial nematode infections, the soil-transmitted helminths (STH) commonly known as intestinal worms are the most common infections worldwide and constitute an important community health problem. The causal parasites are: Ascaris lumbricoides, Trichuris trichiura, and the hookworms Ancylostoma duodenale and Necator americanus. Recent estimates suggest that $A$. lumbricoides infects over 1 billion people, T. trichiura 795 million, and hookworms 740 million. The greatest numbers of
STH infections occur in sub-Saharan Africa, the Americas, China, and East Asia [11]. STH affect most frequently children and produce diarrhea, abdominal pain, general malaise, and weakness that may affect working and learning capacities and impair physical growth and activity. Hookworms cause chronic intestinal blood loss leading to anemia [12-16]. A list of human helminth infections other than filariasis is given in $\bullet$ Table 1.

\section{In vitro and in vivo Systems for Screening Potential Antifilarials \\ $\nabla$}

Being multicellular advanced organisms displaying considerable host specificity, the helminth parasites pose several challenges in the development of convenient and reliable laboratory test systems for assaying plant and synthetic products for anthelmintic and antifilarial activity. In the case of the filarial parasite, there are two main challenges: first, there are 16 distinct human filarial parasite species and the efficacy of the products may show species specificity and parasite stage-specificity. For instance, a product may show about $80 \%$ efficacy against adult worms of Onchocerca spp. but only show an identical or acceptable activity against the larval microfilariae stage of $B$. malayi (unpublished observation). Consequently, to maximize the exploration, a given product, whether active or inactive against one parasite, has to be tested against life stages of multiple species. The second challenge is the availability, maintainability, and responses of some of the target parasites/parasite life stages in vitro and transmission of infection to nonhuman laboratory animal models. For example, the most prevalent lymphatic filariid, $W$. brancrofti, is seldom used for in vitro or in vivo screening. This is because the infection cannot be transmitted to or maintained in small laboratory animals. As a result we do not have a convenient screening model of this parasite and a source of the parasite life stages for in vitro use.

However, our improved understanding in the recent decades of the biology and host parasite interactions helped us developing not only useful in vitro systems but also successful transmission of human infections into small and larger laboratory animals for in vivo screening [18-31].

The different in vitro screen systems developed over the decades and employed for screening plant and synthetic products are given in $\bigcirc$ Table 2. The assays employ one or more life stages $\left(\mathrm{L}_{3}, \mathrm{mf}\right.$, or adult worms) of the parasite depending upon the feasibility or type of activity (larvicidal, microfilaricidal, or macrofilaricidal) desired. The endpoints used in the assays include inhibition (in the parasite) of: motility, reduction of a tetrazolium salt to its formazan, parasite specific glutathione-S-transferase, enzymes involved in antioxidant generation or free radical scavenging, molting of $\mathrm{L}_{3}$ to $\mathrm{L}_{4}$, embryogenesis, and $\mathrm{mf}$ release from female worms. The assays are employed as prescreens either singly or as a battery of two or more assays and the most frequently used battery consists of motility assay and 3-[4,5-dimethylthiazol-2yl]-2,5-diphenyl tetrazolium bromide (MTT) reduction assay. Using this battery, a product is considered active if it causes complete inhibition in motility and/or $>50 \%$ inhibition in MTT reduction. The advantage of the assays are that a) a large number of products can be screened, b) they require a small amount of the test product for the assay, and c) the assays can be completed within 24-48 hrs [32,33]. Investigators have also used $120 \mathrm{hr}$ incubation in order not to miss products that act slowly [34]. The main disadvantage of the in vitro pre-screens is that they detect 
Table 1 Human helminth infections (other than filariasis) [17].

\begin{tabular}{|c|c|c|c|c|c|}
\hline Disease & Parasite & Habitat & $\begin{array}{l}\text { Infective } \\
\text { agent/route }\end{array}$ & $\begin{array}{l}\text { Intermediate } \\
\text { host }\end{array}$ & Clinical manifestations \\
\hline \multicolumn{6}{|c|}{ Nematode infections } \\
\hline Ancylostomiasis & $\begin{array}{l}\text { Ancylostoma duodenale, } \\
\text { A. ceylanicum, Necator } \\
\text { americanus }\end{array}$ & Intestine & $\begin{array}{l}\mathrm{L}_{3} / \text { per os, } \\
\text { skin }\end{array}$ & None & $\begin{array}{l}\text { Creeping eruptions, anemia, } \\
\text { gastrointestinal (G.I.) } \\
\text { manifestations, pot-belly, puffy face }\end{array}$ \\
\hline Ascariasis & Ascaris lumbricoides & Intestine & Eggs/per os & None & $\begin{array}{l}\text { G.I. disturbances: intestinal colic, } \\
\text { obstruction, carbohydrate depletion, } \\
\text { physical and mental retardation, allergy }\end{array}$ \\
\hline Trichuriasis & Trichuris trichiura & Intestine & Eggs/per os & None & Diarrhea, dysentery, pain, rectal prolapses \\
\hline Enterobiasis & Enterobius vermicularis & Intestine & Eggs/per os & None & $\begin{array}{l}\text { Abdominal pain, dysentery, pruritus, rectal } \\
\text { prolapses }\end{array}$ \\
\hline Trichinellosis & Trichinella spiralis & Intestine, muscle & $\begin{array}{l}\text { Encysted } \\
\text { larvae/per os }\end{array}$ & None & $\begin{array}{l}\text { G. I. disturbances, myositis, myocarditis, } \\
\text { neurological symptoms, urticarial rash, } \\
\text { fatal toxemia }\end{array}$ \\
\hline Strongyloidiasis & Strongyloides stercolaris & Intestine & $\mathrm{L}_{3} /$ skin & None & G.I. disturbances \\
\hline \multicolumn{6}{|c|}{ Trematode infections } \\
\hline Schistosomiasis & $\begin{array}{l}\text { Schistosoma mansoni, } \\
\text { S. haematobium, } \\
\text { S. japonicum, S. mekongi, } \\
\text { S. intercalatum }\end{array}$ & $\begin{array}{l}\text { Vasculature } \\
\text { of G.I. or } \\
\text { genito-urinary } \\
\text { systems }\end{array}$ & $\begin{array}{l}\text { Cercariae/ } \\
\text { skin }\end{array}$ & Snail & $\begin{array}{l}\text { Acute: Dermatitis, fever, chills, nausea, } \\
\text { abdominal pain, diarrhea, malaise, and } \\
\text { myalgia } \\
\text { Chronic: Bloody diarrhea (S. mansoni) } \\
\text { or hematuria (S. haematobium) }\end{array}$ \\
\hline \multicolumn{6}{|c|}{ Cestode infections } \\
\hline $\begin{array}{l}\text { Taeniasis and } \\
\text { Echinococcosis } \\
\text { (hydatid disease) }\end{array}$ & $\begin{array}{l}\text { Taenia solium, T. saginata, } \\
\text { Diphyllobothrium spp., } \\
\text { Hymenolepis spp., } \\
\text { Echinococcus multiloccularis }\end{array}$ & Intestine & $\begin{array}{l}\text { Eggs or cysts/ } \\
\text { per os }\end{array}$ & Pig/cow/fish & $\begin{array}{l}\text { Abdominal discomfort, diarrhea, loss } \\
\text { of appetite. Anemia in people with the } \\
\text { fish tapeworm, neurological problems (rare) }\end{array}$ \\
\hline
\end{tabular}

Table 2 In vitro antifilarial assay systems.

\begin{tabular}{|c|c|c|c|}
\hline Assay(s) (Measure/endpoint of the antifilarial activity) & Parasite(s) & $\begin{array}{l}\text { Parasite life stage } \\
\text { employed }\end{array}$ & References \\
\hline \multicolumn{4}{|l|}{ Single assays } \\
\hline \multirow[t]{4}{*}{ Motility (irreversible inhibition of motility of parasite/viability) } & $\begin{array}{l}\text { Litomosoides carinii, Brugia malayi, } \\
\text { Acanthocheilonema viteae }\end{array}$ & Mf & {$[35]$} \\
\hline & B. malayi & Adults & {$[36]$} \\
\hline & B. malayi & $\mathrm{L}_{3}$ & {$[37]$} \\
\hline & B. malayi & Adults, $\mathrm{mf}$ & {$[38]$} \\
\hline Mf release inhibition & B. malayi & Adults & {$[38]$} \\
\hline MTT reduction (inhibition of MTT reduction/viability) & Onchocerca volvulus, O. gutturosa & Female adults & [39] \\
\hline GST Inhibition (Inhibition in parasite GST activity/viability) & B. pahangi, B. malayi & Mf, $\mathrm{L}_{3}$, adults & {$[40]$} \\
\hline Molting inhibition (Inhibition of $\mathrm{L}_{3}$ to $\mathrm{L}_{4}$ molting)/anti-Wolbachia & B. malayi & $\mathrm{L}_{3}$ & {$[41]$} \\
\hline $\begin{array}{l}\text { Octapamine stimulation (tonic paralysis by altered membrane } \\
\text { potentials/viability) }\end{array}$ & A. viteae & Adults & [42] \\
\hline \multicolumn{4}{|l|}{ Two-assay battery } \\
\hline Motility; reduction in lactate excretion (viability) & B. patei and B. malayi & $\mathrm{L}_{3}$, adults & [43] \\
\hline Motility; inhibition of respiration (viability) & L. carinii & & [44] \\
\hline \multirow[t]{7}{*}{ Motility; MTT reduction (viability) } & Setaria cervi & Adult, $\mathrm{mf}$ & [45] \\
\hline & O. volvulus & Adults & [46-49] \\
\hline & O. gutturosa & Adults & {$[47]$} \\
\hline & O. ochengi & Adults, $\mathrm{mf}$ & {$[50]$} \\
\hline & A. viteae & $\mathrm{L}_{3}$, adults, $\mathrm{mf}$ & {$[51,52]$} \\
\hline & B. malayi & Adults, $\mathrm{mf}$ & {$[28,53]$} \\
\hline & S. digitata & Adults & [54] \\
\hline Motility; GST inhibition (viability) & S. cervi & Adult (female) & [55] \\
\hline \multicolumn{4}{|l|}{ Multiple assay battery } \\
\hline \multirow{2}{*}{$\begin{array}{l}\text { Motility; MTT reduction; inhibition of microfilaria release } \\
\text { (embryostatic effect; viability) }\end{array}$} & B. malayi & Adults, $\mathrm{mf}$ & {$[56]$} \\
\hline & B. pahangi & Adults & {$[57,58]$} \\
\hline \multirow{2}{*}{$\begin{array}{l}\text { Antioxidant enzyme inhibition (inhibition of xanthine-oxidase, } \\
\text { superoxide dismutase, catalase, glutathione peroxidase/viability) }\end{array}$} & B. pahangi & Adults & {$[57,58]$} \\
\hline & L. carinii, S. cervi & Adults & [59] \\
\hline
\end{tabular}


antifilarial activity of only those products which do not require metabolic activation to active pharmacophore. As a result several products that are negative in vitro but which may show activity after bitransformation in the host are missed. It is therefore necessary to include in the in vitro incubations a metabolic activation system such as the liver microsomal fraction (S9 mix) rich in most of the cytochrome P450 isoforms. An (expensive) alternative is testing all products, whether active or inactive in vitro, in suitable animal models of the infection.

Although tests employing animal models are labor intensive, expensive, lengthy, and often difficult to scale-up, they are sufficiently reliable, and the conclusions drawn from them are frequently transferable to human infection, provided sufficient care is taken in the selection of the host-parasite system.

Our understanding of the host-parasite interactions and immune responses of the host in human filariasis and in a variety of animal models of the human infection has greatly improved in recent years [20,60-62] and as a result we now have well-characterized animal models for assaying antifilarial activity ( Table 3 ).

Historically, attempts to transmit the human filarial infections to laboratory animals were unsuccessful. This necessitated the use of alternative animal models for antifilarial drug discovery programs. One of the earliest models is Litomosoides carinii infection in the cotton rat. Introduced in 1944 [63], this was used as a primary screen and was instrumental in the discovery of the microfilaricide diethylcarbamazine (DEC). However a major drawback with this model was that the host can only be infected through the vector but not by manual injection of infective larvae. So, there is no way of knowing how many, if at all, infective larvae had been introduced into the host by the vector. This is important for reproducible 1 ) determination of the percent yield of adult worms (= \% larvae surviving and developing in to adult worms), and 2) quantifying the macrofilaricidal and worm sterilizing effect of the test drug. Another model which was established in '70s is Acanthocheilonema viteae in the jird (Meriones unguiculatus) and in Mastomys coucha. These models overcame the deficiencies of the $L$ carinii/cotton rat model and were considered acceptable [64] as a surrogate primary screen for products against human 0 . volvulus infection. However, for a long time there was still no rodent model for human lymphatic filarial infections with $W$. bancrofti and B. malayi. The real breakthrough came with the successful transmission of $B$. malayi to the rodents jird $[65,66]$ and Mastomys coucha $[18,67,68]$ and recently, to nonhuman primates $[25,29,31,69]$. In $M$. coucha the infection is introduced by subcutaneous injection of a known number of $\mathrm{L}_{3}$. In jird, in addition to the s.c. route, the infection can also be initiated by intraperitoneal instillation of a known number of adult worms or $\mathrm{L}_{3}$. The latter method not only makes the animal microfilaremic in a short period but is especially useful for assaying macrofilaricidal efficacy of products by following the fate of instilled worms. Both the rodent models show high and sustained microfilaraemia for prolonged periods which is advantageous for assaying microfilaricides. An additional feature of the $M$. coucha is its susceptibility to develop filarial disease manifestations (unpublished observation).

Among nonhuman primates, the leaf monkeys (Presbytis spp.) were found to be especially susceptible to $B$. malayi infection $[25,29]$ and among them the Indian leaf monkey displays responses similar to those shown by human subjects harboring the infection, including the recurrent febrile and limb edema episodes, hydrocoele, and eosinophilia [29].
With the availability of adequate animal models of human filarial infection, the new product screening protocol has been revised by the WHO. At the authors' Institute the protocol conducted is largely based on WHO recommendations and is as follows:

Prescreen: In vitro motility and MTT assays using adult worms and $\mathrm{mf}$ of $\mathrm{B}$. malayi for short-listing. This is followed by $\mathrm{IC}_{50}$ (the concentration at which the parasite motility is inhibited by $50 \%$ ) determination using the same assays and $\mathrm{CC}_{50}$ (cytotoxic concentration at which $50 \%$ of cells are killed) determination using VERO Cell line C1008 (African green monkey kidney cells) [33, 89-91].

Primary screening: Jird bearing i.p. instilled adult worms of B. malayi.

Confirmation of efficacy: $\mathrm{L}_{3}$-initiated infection of $B$. malayi in M. coucha or jird.

Dose optimization studies: $\mathrm{L}_{3}$-initiated infection of B. malayi in M. coucha.

Efficacy in a non-rodent or nonhuman primate model (previously called as tertiary screen): $\mathrm{L}_{3}$-initiated infection of $B$. malayi in non-rodent/nonhuman primate model.

\section{Assay Systems for Screening Plants against Helminth Parasites Other Than Filariae} $\nabla$

\section{In vitro (primary) screens}

For screening potential synthetic or plant derived anthelmintics (other than antifilarials) several nematode, cestode, and trematode parasites have been used in in vitro systems ( Table 4). The selection of parasites for the in vitro systems is apparently based on considerations such as easy availability, adaptability to laboratory conditions, ease in handling, and, when the human parasite cannot be used, the similarities between human and surrogate parasite responses to known drugs and/or taxonomical proximity of the species chosen. This approach would appear justified by several instances of intergeneric chemotherapeutic responses within the same family. Among nematodes, such a relationship is known to exist between murine oxyurid and Enterobius vermicularis with piperazine; between Nippostrongylis muris and trichostrongyles of sheep and cattle or hookworms of man and dog with bephenium and between Strongyloides ratti and S. stercolaris with dithiazanine [92].

\section{In vivo}

- Tables 5 and $\mathbf{6}$ show a list of animal models for primary and secondary screening, respectively. The in vivo primary and secondary screening would strengthen the results obtained in the in vitro prescreening. The in vivo screens will also demonstrate whether the spectrum of activities can be extended to the related parasites in different hosts and to efficacy in human subjects.

Parasites having a short and direct life cycle needing no vector would obviously need less time and labor and would be economical to generate results. Hymenolepsis nana, a human tapeworm, in natural condition, is cycled through intermediate host (Tribolium confusum) but also attains maturity in one and the same host within 15 days of incubation of eggs. This system will also facilitate the assessment of drugs against cysticercoides and adult worms in the same infected animal. Small hosts with minimum genetic variations and easily available in adequate numbers are usually preferred for reproducibility.

Inspite of all the care exercised in selecting the best host-parasite system, the results obtained in experimental hosts can not totally 
Table 3 Animal models of nonhuman and human filarial infections.

\begin{tabular}{|c|c|c|c|c|c|}
\hline Parasite & Host & Vector & $\begin{array}{l}\text { Initiation/introduction } \\
\text { of infection }\end{array}$ & $\begin{array}{l}\text { Site of adult worms/ } \\
\text { microfilariae }\end{array}$ & Reference \\
\hline \multicolumn{6}{|c|}{ 1. Rodent and non-rodent models of nonhuman filarial infections } \\
\hline \multirow[t]{3}{*}{ Litomosoides cariniï $^{*}$} & Sigmodontis hispidus\# & Mite & $\mathrm{L}_{3}$ (s.c.) & Pleural cavity/blood & {$[63,70-74]$} \\
\hline & Mastomys coucha & & & & \\
\hline & Meriones unguiculatus & & & & \\
\hline \multirow[t]{5}{*}{ Acanthocheilonema viteae } & M. unguiculatus & Tick & $\mathrm{L}_{3}$ (s.c.) & $\begin{array}{l}\text { Subcutaneous and inter- } \\
\text { nal connective tissues/ } \\
\text { blood }\end{array}$ & {$[75,76]$} \\
\hline & M. lybicus & & & & \\
\hline & M. persicus & & & & \\
\hline & M. coucha & & & & \\
\hline & Mesocricetus auratus & & & & \\
\hline \multirow[t]{5}{*}{ Brugia pahangi } & M. unguiculatus & Mosquito & $\begin{array}{l}L_{3} \text { (s.c.), adult worms } \\
\text { (i. p.) }\end{array}$ & $\begin{array}{l}\text { Testes, heart, lungs/ } \\
\text { blood }\end{array}$ & {$[69,75,77-79]$} \\
\hline & M. coucha & & & & \\
\hline & $\mathrm{CDI}$ and $\mathrm{Balb} / \mathrm{c}$ mice & & & & \\
\hline & Dog & Mosquito & $\mathrm{L}_{3}$ (s.c.) & Lymphatics/blood & \\
\hline & Cat & & & & [80] \\
\hline Dirofilaria immitis & Dog & Mosquito & $\mathrm{L}_{3}$ (s.c.) & $\begin{array}{l}\text { Heart, pulmonary } \\
\text { arteries, venae cavae/ } \\
\text { blood }\end{array}$ & {$[41,80]$} \\
\hline \multicolumn{6}{|c|}{ 2. Rodent and non-rodent models of human filarial infections } \\
\hline \multirow[t]{3}{*}{ B. malayi* } & M. unguiculatus* & Mosquito & $\begin{array}{l}L_{3} \text { (s.c.), adult worms } \\
\text { (i. p.) }\end{array}$ & $\begin{array}{l}\text { Lymphatics, testes, } \\
\text { heart, lungs/blood }\end{array}$ & $\begin{array}{l}{[21,53,66,68} \\
69,81-83]\end{array}$ \\
\hline & M. coucha* & & $\mathrm{L}_{3}$ (s.c.) & & \\
\hline & Balb/c mice & & $\mathrm{L}_{3} /$ adult worms (i.p.) & & \\
\hline \multirow[t]{2}{*}{ B. malayi } & Dog & Mosquito & $\mathrm{L}_{3}$ (s.c.) & Lymphatics/blood & {$[69,80]$} \\
\hline & Cat & & & & \\
\hline \multicolumn{6}{|c|}{ 3. Nonhuman primate models of human filarial infections } \\
\hline \multirow[t]{9}{*}{ B. malayi** } & Erythrocebus patas & Mosquito & $L_{3}$ (s.c.) & Lymphatics/blood & {$[25,29-31,69,84-86]$} \\
\hline & Nyticebus coucang & & & & \\
\hline & $\begin{array}{l}\text { Galago crassicaudatus pan- } \\
\text { ganiensis }\end{array}$ & & & & \\
\hline & Papio cynocephalus & & & & \\
\hline & Cercopithecus aethiops & & & & \\
\hline & Macaca mulatta & & & & \\
\hline & Presbytis entellus** & & & & \\
\hline & P. melalophos & & & & \\
\hline & P. cristata & & & & \\
\hline Wuchereria bancrofti & P. entellus & Mosquito & $L_{3}$ (s.c.) & Lymphatics/blood & [87] \\
\hline \multirow[t]{2}{*}{ Breinlia sergenti } & Nycticebus coucang, & Mosquito & $\mathrm{L}_{3}$ (s.c.) & Peritoneal cavity & {$[80,88]$} \\
\hline & $\begin{array}{l}\text { Papio anubis, Erythrocebus } \\
\text { patas }\end{array}$ & & & & \\
\hline Loa loa & Mandrillus leucophaeus & Chrysops & $\mathrm{L}_{3}$ (s.c.) & $\begin{array}{l}\text { Subcutaneous and } \\
\text { connective tissues/blood }\end{array}$ & {$[80,88]$} \\
\hline Onchocerca volvulus & Pan troglodytes & Simulium & $\mathrm{L}_{3}$ (s.c.) & $\begin{array}{l}\text { Subcutaneous tissues/ } \\
\text { blood }\end{array}$ & {$[80,88]$} \\
\hline
\end{tabular}

\# Earlier used as a primary screen. * Models currently employed as a primary screen for assaying potential antifilarial products at CDRI. ${ }^{* *}$ Models employed as final preclinical confirmation (previously called as tertiary screen) assays at CDRI

be translated to the target parasite in its natural host because the different compounds behave differently in different hosts (absorption, kinetics, resorption and distribution, etc.) [104]. This might be crucial for decision making regarding whether or not it should enter successive steps of drug development program. The different in vitro and in vivo systems, their utility and drawbacks have been recently reviewed by Keiser [101].

\section{Plants for Filariasis}

$\nabla$

In modern medicine the drugs used for lymphatic filariasis are diethylcarbamazine (DEC) [70] and ivermectin [105], and a singledose treatment with DEC or ivermectin, or combination of DEC or ivermectin with albendazole is currently employed in an attempt to control the infection. DEC and ivermectin are microfilaricides and therefore only useful in reducing transmission and pathology. New drugs are required to improve treatment by killing the adult worms (macrofilariae), which are long-lived, and to replace the currently used drugs before drug resistance starts appearing [106]. 
Table 4 In vitro parasite systems (other than filaria) for screening anthelmintic activity.

\begin{tabular}{|c|c|c|c|}
\hline Parasite (host) & Life stages & Assay(s)/measure of the anthelmintic activity & References \\
\hline \multicolumn{4}{|l|}{ Nematodes } \\
\hline $\begin{array}{l}\text { Trichostrongylus colubriformis } \\
\text { (human infection) }\end{array}$ & $\begin{array}{l}\text { Eggs, } L_{3} \text { (infective } \\
\text { larvae), adult worms }\end{array}$ & $\begin{array}{l}\text { Egg hatch inhibition assay (EH), larval development assay (LD), } \\
\text { larval migration inhibition (LMI), adult worm viability }\end{array}$ & {$[93-96]$} \\
\hline $\begin{array}{l}\text { Haemonchus contortus } \\
\text { (ruminants) }\end{array}$ & $\begin{array}{l}\text { Eggs, infective larvae, } \\
\text { adult worms }\end{array}$ & Egg hatch inhibition assay (EH), larval migration inhibition (LMI) & {$[93,97,98]$} \\
\hline $\begin{array}{l}\text { Ancylostoma caninum (human) } \\
\text { Necator americanus (human) }\end{array}$ & Larvae, adults & Motility/irreversible inhibition of motility & {$[93]$} \\
\hline $\begin{array}{l}\text { Ascaris suum (pig \& human) } \\
\text { A. lumbricoides (human) } \\
\text { Ascaridia galli (chicken/turkey) } \\
\text { Heterakis gallinarum (chicken/turkey) } \\
\text { Toxocara canis }\end{array}$ & $\begin{array}{l}\text { Adult worms, 2nd } \\
\text { stage larva }\end{array}$ & Motility/irreversible inhibition of motility & {$[99,100]$} \\
\hline \multicolumn{4}{|l|}{ Cestodes } \\
\hline Raillietina echinobothrida (fowl) & Adult worms & Motility/irreversible inhibition of motility & [99] \\
\hline \multicolumn{4}{|l|}{ Trematodes } \\
\hline $\begin{array}{l}\text { Paramphistomum sp. } \\
\text { (cattle, sheep, goat) }\end{array}$ & Adult worms & Motility/irreversible inhibition of motility & {$[99]$} \\
\hline $\begin{array}{l}\text { Schistosoma mansoni } \\
\text { Fasciola hepatica } \\
\text { Echinostoma caproni } \\
\text { (all human infections) }\end{array}$ & Adult worms & Motility/irreversible inhibition of motility & {$[101]$} \\
\hline
\end{tabular}

Table 5 Helminth parasites used for in vivo primary screening* [17, 100, 102, 103].

\begin{tabular}{|c|c|c|c|c|}
\hline Parasite & Host/intermediate host & Infective agent/route & Model for & Clinical correlation ${ }^{@}$ \\
\hline \multicolumn{5}{|l|}{ Nematodes } \\
\hline Ascaris suis (suum) & Mouse/none & Eggs/per os & Ascariasis & +++ \\
\hline Necator amaricanis & Hamster/none & $\mathrm{L}_{3} /$ skin & Ancylostomiasis & +++ \\
\hline Ancylostoma ceylanicum & Hamster/none & $\mathrm{L}_{3} /$ per os & -do- & +++ \\
\hline Nippostronglys brasiliensis & Hamster/none & $\mathrm{L}_{3} /$ per os & -do- & +++ \\
\hline \multicolumn{5}{|l|}{ Cestodes } \\
\hline Hymenolepis nana & Mouse/beetle ${ }^{\#}$ & Eggs/per os & Taeniasis & +++ \\
\hline H. diminuta & Rat/beetle & Eggs/per os & -do- & ++ \\
\hline \multicolumn{5}{|l|}{ Trematodes } \\
\hline Fasciola hepatica & Rat, rabbit/snail & Metacircariae/per os & Fascioliasis & ++ \\
\hline F. gigantica & Rat/rabbit/snail & -do- & -do- & ++ \\
\hline Schistosoma mansoni & Mouse, hamster/snail & Cercariae/skin & Schistosomiasis & +++ \\
\hline \multirow[t]{4}{*}{ S. japonicum } & Mouse/snail & -do- & -do- & +++ \\
\hline & Hamster/snail & -do- & -do- & ++ \\
\hline & Rabbit/snail & -do- & -do- & ++ \\
\hline & Guinea pig/snail & -do- & -do- & ++ \\
\hline
\end{tabular}

\# Intermediate host not obligatory; ${ }^{@}$ scale: ++= moderate; +++ = high

Table 6 Test models for in vivo secondary screening [17].

\begin{tabular}{|c|c|c|c|}
\hline Parasite & Host/intermediate host & Model for & Clinical correlation \\
\hline \multicolumn{4}{|l|}{ Nematodes } \\
\hline Ascaridia galli & Chicken/none & Ascariasis & +++ \\
\hline Toxocara canis & Dog/none & -do- & ++ \\
\hline Toxascaris leonina & Cat/none & -do- & ++ \\
\hline Ancylostoma caninum & Dog/none & Ancylostomiasis & +++ \\
\hline A. brasiliense & Dog, cat/none & - do- & +++ \\
\hline A. tubaeforme & Cat/none & -do- & ++ \\
\hline \multicolumn{4}{|l|}{ Cestodes } \\
\hline Taenia hydatigna & Dog/ruminants & - do- & +++ \\
\hline T. taeniaeformis & Cat/rodents & - do- & +++ \\
\hline Dipylidium caninum & Dog/fleas & Taeniasis & +++ \\
\hline T. pisiformis & Dog/rabbit & -do- & +++ \\
\hline Cysticiercus pisiformis (larva of T. taeniaeformis) & Rabbit & Cysticercosis & ++ \\
\hline Echinococcus cyst (intermediate stage of $E$. granulosus) & Rabbit & Hydatid disease & ++ \\
\hline
\end{tabular}


In the last few decades a lot of emphasis has been laid on the development of antifilarial agents from plant or natural products by many investigators $[32,48,82,107,108]$ and to develop traditional plant-based medical preparations incomplementary or alternative medicines (CAM) supported by scientific validation of efficacy and safety and quality control of the preparations. Although there are few specific reports on the antifilarial properties of plant extracts or products, it is not unusual to find these indications cited amongst a general list of medicinal plants $[109,110]$. Some plants are reported to be active against tissue dwelling nematodes and various filarial species and are used in traditional systems of medicine [111]. OTable 7 shows a list of plants studied for activity against filarial parasites [112]. Some of these are tested for their antifilarial activity mostly in vitro and some in vivo. Among these, Streblus asper, a plant used in traditional medicine for lymphedema, is the only plant that has been studied extensively and systematically in vitro as well as in vivo and whose active constituents were chemically characterized. A preparation of plant decoction named "filacid" made from the stem bark of $S$. asper has been administered to over 5000 filarial patients at a filaria clinic in Varanasi, India, during the period $1970-1987[113,114]$ and was found to be effective in the treatment of filarial lymphedema, filarial chyluria, and other conditions of the disease. In comparative trials, other plants used in traditional medicine were found to be less effective (viz. Crataeva nurvala [7\%], Argyreia nervosa [48\%], Butea monosperma [12\%]) than "filacid" in the treatment of filarial lymphedema $[112,113]$. Later, the stem bark extract was found to be active against several filarial species including $B$. malayi in vitro and in vivo. The active principles were identified as two cardiac glycosides, asperoside and strebloside [107]. For onchocerciasis, there are relatively fewer reports of plant-based traditional medicine in the literature. Aloe barteri was cited for the treatment of 0 . volvulus-induced skin conditions [109]. Another plant, Cassia aubrevellei, which is believed in Liberia to be useful in skin conditions associated with onchocerciasis, was found to be inactive against female parasites recovered from nodules of patients [115]. On the contrary, the plant extract increased the density of skin microfilariae [116]. Extracts of some Cameroonian plants like Carapa procera, Pachypodanthium staudth, and Polyalthia sauveolens were also found to be effective against filarial parasites. The active principles of these plants were identified as carapolide A and oliverine and were tested against 0 . volvulus in vitro by Titanji et al. [117]. Cardol, a phenolic compound isolated from Anacardium occidentale is reported to be active against bovine filariid $S$. cervi in vitro [118]. Other in vitro/in vivo investigations of plant extracts have also been reported against various filarial species [116,119-123]. Both aqueous and alcoholic extracts of the leaves of Mallotus philippensis and Sencio nudicaulis were effective in inhibiting the movements of the nerve-muscle (n.m.) preparation of $S$. cervi. The stimulatory response of acetylcholine was blocked by the aqueous extract on whole worm movements [124]. The effect of S. nudicaulis extracts was different from that produced by the calcium channel blocker nifedipine on the whole worm and n.m. preparation. While nifedipine blocks the stimulant effect of Ach, the extract of $S$. nudicaulis fails to do so. This response bears similarity with DEC, which also does not block AchE response. However, interpretation of these activities in terms of target filarial infections in vivo is difficult.

The majority of the filaricidal applications of plant products reported in the early literature are for the treatment of guinea worm (Dracunculus sp.) which was earlier considered as a filarial parasite but is now included in a separate group. Plant extracts are in many cases applied externally to the sore caused by guinea worm indicating that most of the observed effects may be due to direct topical effect of the agent on the parasite or wound. Several plant products were also reported active when given orally. Root decoction of Combretum micranathum was reported to help in expelling guinea worms in infested patients; inflammation around the lesions was also reduced [125]. The leaves of Elaeophorbia drupifera and Hilleria latifolia taken in combination with a palm soup preparation were found to be guinea wormicidal [125].

In laboratory investigations several plant products were identified with antifilarial activity. In vitro, macrofilaricidal activity was shown by ethanolic and aqueous extracts of the medicinal plant Cardiospermum halicacabum against B. pahangi in terms of reduced motility of both male and female adult worms and reduced microfilarial release and motility (ethanolic extract) [126]. Methanolic extracts of the root of Vitex negundo L. (containing alkaloids, saponin, and flavonoids) and leaves of Aegle marmelos Corr. (containing coumarins) produced complete loss of motility of microfilariae of B. malayi [127]. Extracts of Butea monosperma leaves and roots showed significant inhibition of motility in a dose-dependent manner of $B$. malayi microfilariae [32]. In animal models, crude extract and hexane fraction of marine red alga Botryocladia leptopoda killed adult filarial parasites of $L$. sigmodontis and A. viteae and caused sterilization of B. $m a-$ layi female worms [128]. Crude extract and chloroform fraction of the stem portion of the plant Lantana camara showed adulticidal and female worm sterilizing activity against $B$. malayi in $M$. coucha and in jirds with i.p. instilled B. malayi adult worms. Oleanonic and oleanolic acids isolated from the hexane and chloroform fractions showed considerable antifilarial activity on B. malayi in vitro. Inhibition of motility and subsequent mortality of adult worms of $S$. digitata was produced in vitro by extracts of Cedrus deodara, Ricinus communis, Sphaeranthus indicus, and Centratherum anthelminticum in decreasing order [54]. Crude extract (and an active fraction of it) of Trachyspermum ammi fruit inhibited motility and killed S. digitata worms in vitro and showed macrofilaricidal and female sterilizing efficacy in vivo against $B$. malayi in $M$. coucha. The active compound was isolated and found to be a phenolic monoterpene [129]. Potential microand macrofilaricidal efficacy against $B$. pahangi was shown by ethanol extract of leaves of Neurolaena lobata, a Guatemalan medicinal plant [58]. Aqueous, butanol, and hexane extracts of Caesalpinia bonducella-seed kernel demonstrated microfilaricidal, macrofilaricidal, and female-sterilizing efficacy against L. sigmodontis in cotton rats and microfilaricidal activity against B. malayi in $M$. coucha [130].

\section{Plants for Helminthiasis (Other Than Filariasis)}

$\nabla$

The literature concerning the use of plants as anthelmintics ( Table 8) is more extensive $[158,159]$ and preparations from many of these plants are in current use. With few exceptions, e.g. the investigation by Kiuchi et al. [111] on tissue dwelling nematodes, the majority of them are effective against intestinal helminths. The most widely known and investigated anthelmintics of plant origin are ascaridole, derived from Chenopodium ambrosoides [158] and the phloroglucinols aspidin and deaspidin, from the male fern Dryopteris filix mas. They are used effectively to treat tapeworm infections [160]. Some of the plant 
Table 7 Plant products with activity in filariasis or against the parasites.

\begin{tabular}{|c|c|c|c|c|}
\hline Name of the plant & Family & Part used/product & Activity against & Reference \\
\hline Adenia gummifera & Passifloraceae & Root & Filariasis, hydrocoele & [131] \\
\hline Aegle marmelos Corr. & Euphorbiaceae & Leaf & Mf of $B$. malayi (in vitro) & {$[32,127]$} \\
\hline Afstonia boonei & Apocynaceae & $\begin{array}{l}\text { Bark, fresh latex, } \\
\text { fresh stem bark }\end{array}$ & Loaiasis, filarial swellings & [132-134] \\
\hline Agrimonia eupatoria & Rosaceae & Agrimophol & $\begin{array}{l}\text { Schistosoma sp } \\
\text { Taenia sp }\end{array}$ & [135] \\
\hline Alstonia congensis & Apocynaceae & Latex & $\begin{array}{l}\text { Loaiasis, filarial swellings (bandaged along with } \\
\text { crushed bark of Erythrophleum guineense) }\end{array}$ & [109] \\
\hline Alstonia scholaris & Apocynceae & Latex, bark & Filariasis, elephantiasis & [136] \\
\hline Aloe barteri & Liliaceae & Leaf & $\begin{array}{l}\text { Guinea worm, disease causing white skin } \\
\text { patches (onchocerciasis?) }\end{array}$ & [109] \\
\hline Ammannia multiflora & Lythraceae & Leaf & Sight problems, including those caused by filaria & [131] \\
\hline Andrographis paniculata & Acanthaceae & Dried leaf & $\begin{array}{l}\text { Filariasis, } \mathrm{mf} \text { of } D \text {. reconditum in dogs (in vivo and } \\
\text { in vitro) and adults of } B \text {. malayi in rodents }\end{array}$ & [120] \\
\hline Argyreia speciosa & Convolvulaceae & Whole plant & $\begin{array}{l}\text { Filariasis, parasitic skin diseases, active in vitro } \\
\text { against S. cervi }\end{array}$ & {$[137,138]$} \\
\hline Azadirachta indica & Meliaceae & Leaf, flower & S. digitata (in vitro) & {$[139,140]$} \\
\hline Boerhavia repens & Nyctaginaceae & Immature shoots & Elephantiasis & [109] \\
\hline Botryocladia leptopoda & Rhodymeniaceae & Red algae & L. sigmodontis, A. viteae, B. malayi (in vivo) & [128] \\
\hline Butea monosperma & Leguminosae-Papilioneae & Root and leaf & Mf of B. malayi (in vitro) & [127] \\
\hline Caesalpinia bonducella & Caesalpiniaceae & Seed kernel & S. digitata (in vitro), L. sigmodontis, B. malayi (in vivo) & [130] \\
\hline Calotropis gigantea & Asclepiadaceae & Leaf, latex & $\begin{array}{l}\text { Filariasis, elephantiasis, skin changes, S. digitata } \\
\text { (in vitro) }\end{array}$ & {$[109,140,141]$} \\
\hline Calotropis procera & Asclepiadaceae & $\begin{array}{l}\text { Whole plant/milky juice, } \\
\text { dried aerial parts, root, bark, } \\
\text { latex }\end{array}$ & Guinea worm; filariasis, elephantiasis & $\begin{array}{l}{[109,136,142-} \\
144]\end{array}$ \\
\hline Carapa procera & Meliaceae & Dried fruit, seed & $\begin{array}{l}\text { Filariasis, O. volvulus (in vitro), parasitic skin } \\
\text { disease }\end{array}$ & {$[117,145]$} \\
\hline $\begin{array}{l}\text { Cardiospermum } \\
\text { halicacabum }\end{array}$ & Sapindaceae & Plant & B. pahangi adult and $\mathrm{Mf}$ (in vitro) & [126] \\
\hline Cassia alata & Leguminosae & Fresh leaf juice & Parasitic skin disease & {$[117,122]$} \\
\hline Cassia aubrevellei & Leguminosae & Root, bark & $\begin{array}{l}\text { Onchocerciasis, skin microfilaricidal, active in vi- } \\
\text { tro against } O \text {. volvulus } \mathrm{mf}\end{array}$ & [138] \\
\hline Cassia occidentalis & Leguminosae & Leaf, seed & $\begin{array}{l}\text { Guinea worm, parasitic skin diseases } \\
\text { acute lymphedema, skin changes }\end{array}$ & [109] \\
\hline Cassia tora & Leguminosae & Dried leaf & Parasitic skin diseases & {$[109,141]$} \\
\hline Cayaponia martiana & Cucurbitaceae & Root & Elephantiasis & [109] \\
\hline Cedrus deodara & Pinaceae & Plant extract & S. digitata adults (in vitro) & [54] \\
\hline $\begin{array}{l}\text { Centratherum } \\
\text { anthelminticum }\end{array}$ & Asteraceae & Plant extract & S. cervi, S. digitata adults (in vitro) & [54] \\
\hline Cinnamomum culilawan & Lauraceae & Bark & Rubeifacient for filarial lymphangitis & [109] \\
\hline Cleistopholis glauca & Annonaceae & Dried bark & Filariasis, inactive in vitro against $O$. volvulus & [109] \\
\hline Clerodendrum capitum & Verbenaceae & Root & Elephantiasis & [109] \\
\hline Crossopteryx febrifuga & Rubiaceae & Fresh fruit juice & Eye filaria & [125] \\
\hline Cyrotomium fortunei & Polypodiaceae & Dried rhizome & Filariasis & [133] \\
\hline Daniella thurifera & Leguminosae & Gum & Parasitic skin diseases & [146] \\
\hline Delonix elata & Leugminosae & Whole plant & Filariasis, elephantiasis & [109] \\
\hline $\begin{array}{l}\text { Dichrostachys cinerea } D . \\
\text { glomerata }\end{array}$ & Leguminosae & Dried stem bark, inner bark & Elephantiasis & {$[142,147]$} \\
\hline Dombeya amaniensis & Steruliaceae & Root & Filariasis/lymphatic disorders & [148] \\
\hline Eclipta alba & Compositae & Dried whole plant & Elephantiasis & [109] \\
\hline \multirow[t]{2}{*}{ Elaeophorbia drupifera } & Euphorbiaceae & Leaf & Guinea worm, filariasis & {$[131,145]$} \\
\hline & & Leaf & Guinea worm, used with Hilleria latifolia & [109] \\
\hline Elephantopus scaber & Compositae & Dried root & Filariasis & [141] \\
\hline Emicostema littorale & Gentianaceae & Whole plant & $\begin{array}{l}\text { Filariasis, microfilaricidal } \\
\text { in vitro against Conispiculum guindiensis }\end{array}$ & [125] \\
\hline Erythophleum guineense & Leguminosae & Crushed bark & $\begin{array}{l}\text { Loaiasis (filarial swellings), used with } \\
\text { Alstonia congensis }\end{array}$ & [149] \\
\hline Erythophleum ivorense & Leguminosae & Dried stem bark & Loaiasis (filarial swellings) used in $O$. volvulus & [119] \\
\hline Eucalyptus robusta & Myrtaceae & Leaf & Microfilariasis & [109] \\
\hline Guiera senegalensis & Combretaceae & Leaf & $\begin{array}{l}\text { Parasitic skin diseases, guinea worm } \\
\text { inflammatory swellings }\end{array}$ & [109] \\
\hline Hilleria latifolia & Phytolaccaceae & Whole plant, leaf & $\begin{array}{l}\text { Guinea worm, used with Elaeophorbia drupifera; } \\
\text { filariasis, O. volvulus (in vitro) }\end{array}$ & {$[109,150]$} \\
\hline
\end{tabular}


Table 7 Plant products with activity in filariasis or against the parasites. (continued)

\begin{tabular}{|c|c|c|c|c|}
\hline Name of the plant & Family & Part used/product & Activity against & Reference \\
\hline Jatropha curcas & Euphorbiaceae & Seed oil, leaf, whole plant & $\begin{array}{l}\text { Guinea worm, rubefacient for parasitic } \\
\text { skin diseases }\end{array}$ & {$[122,125,141]$} \\
\hline Kigelia africana & Bignoniaceae & Whole plant & Elephantiasis of scrotum & [109] \\
\hline Lantana camara & Verbenaceae & Stem & A. viteae, B. malayi & [108] \\
\hline Limeum ptercarpum & Molluginacaeae & Aerial parts & Filariasis & [141] \\
\hline Lawsonia inermis & Lythraceae & Leaf & S. digitata (in vitro) & [140] \\
\hline Lycopodium rubrum & Lycopodiaceae & Whole plant & Elephantiasis & [151] \\
\hline Mallotus philippensis & Euphorbiaceae & Leaf & S. cervi (in vitro) & [124] \\
\hline Melia azidirachta & Meliaceae & Bark & Filariasis, component (15\%) of FILARIN & [152] \\
\hline Microglossa afzelii & Compositae & Dried leaf & Filariasis, O. volvulus (inactive in vitro) & {$[124]$} \\
\hline Mussaenda elegans & Rubiaceae & Leaf & Elephantiasis & {$[109,125]$} \\
\hline Myrianthus arboreus & Moraceae & Dried stem bark & Filariasis, O. volvulus (inactive in vitro) & [109] \\
\hline Newbouldia laevis & Bignoniaceae & Root and leaf & Elephantiasis, scrotal elephantiasis, orchitis & {$[122,153]$} \\
\hline Neurolaena lobata & Asteraceae & Leaf & B. pahangi adults (in vitro) & [58] \\
\hline Ocimum sanctum & Lamiaceae & Leaf & S. digitata (in vitro) & [140] \\
\hline Ochrocarpus africanus & Guttiferae & Root/resinous sap & Parasitic skin diseases & [109] \\
\hline Odyendea gabunensis & Simaroubaceae & Dried stem bark & Filariasis, O. volvulus (inactive in vitro) & [154] \\
\hline Pachyelasma tessmanii & Leguminosae & Dried fruit & Filariasis, O. volvulus (in vitro) & [122] \\
\hline Pachylobus edulis & Buseraceae & Bark & Parasitic skin diseases & [141] \\
\hline Pachypodanthium staudtii & Annonaceae & Dried stem bark & Filariasis, O. volvulus (in vitro) & {$[117,122]$} \\
\hline Physedra longipes & Cucurbitaceae & Whole plant & Elephantiasis of scrotum & {$[117,122]$} \\
\hline Phychotria tanganyikensis & Rubiaceae & Leaf & Elephantiasis & [109] \\
\hline \multirow[t]{2}{*}{ Raphia farinifera } & Palmae & Dried fruit & Filariasis, O. volvulus (in vitro) & [155] \\
\hline & & Dried leaf & Filariasis, O. volvulus (in vitro) & [122] \\
\hline Ricinus communis & Euphorbiaceae & Plant extract, leaf & $\begin{array}{l}\text { S. digitata adults (in vitro); Mf of B. malayi } \\
\text { (in vitro) }\end{array}$ & {$[32,54,127]$} \\
\hline Richiea caparoides & Capparidaceae & Leaf, root & Filariasis; guinea worm & {$[122,141]$} \\
\hline Rynchosia hirta & Leguminosae & Whole plant & Filariasis, elephantiasis & [156] \\
\hline Sargentodoxa cuneata & Sargentodoxaceae & Dried stem & Filariasis & [147] \\
\hline Sencio nudicaulis & Asteraceae & Leaf & S. cervi mf (in vitro) & [109] \\
\hline Sphaeranthus indicus & Asteraceae & Plant extract & S. digitata adults (in vitro) & [54] \\
\hline Streblus asper & Urtaceae & Stem bark & $\begin{array}{l}\text { Filarial lymphedema, micro- and macro-filaricidal, } \\
\text { S. cervi, L. carinii, B. malayi, A.viteae, B. malayi }\end{array}$ & $\begin{array}{l}{[107,113,114,} \\
123,157]\end{array}$ \\
\hline Trachyspermum ammi & Apiaceae & Fruit & S. digitata adults (in vitro), B. malayi (in vivo) & [129] \\
\hline Terminalia chebula & Combretaceae & Not known & Filariasis & [109] \\
\hline Tinospora cordifolia & Menispermaceae & Not known & Filariasis (acute lymphedema, skin changes) & [112] \\
\hline Xerodermis stuhlmannii & Leguminosae & Root & Elephantiasis & [138] \\
\hline Vitex negundo L. & Euphorbiaceae & Root, leaf & Mf of B. malayi (in vitro) & {$[32,127]$} \\
\hline Zingiber officinale & Zingiberaceae & Fresh rhizome & $\begin{array}{l}\text { Filariasis, D. immitis (microfilaricidal) } \\
\text { (acute lymphedema) }\end{array}$ & {$[121,152,154]$} \\
\hline
\end{tabular}

products are vermicides while others are vermifuges. Oil of chenopodium (ascaridole) is effective against Ascaris and hookworms but is highly toxic. Aspidum is one of the oldest used anthelmintics obtained from the rhizomes of the fern Dryopteris filix mass. Polyhydric phenol is its active principle (filicic acid and filicin). The product has specific action against intestinal cestodes: Diphyllobothrium, Taenias, Hymenolepis spp and others, and acts probably by paralyzing the muscles of parasites. However, the drug is toxic and causes polyneuritis and paralysis of the iris. Santonin is the oil obtained from the seeds of Artemisia maritima. Flowering tops of this plant were used by physicians of Greece as early as $60 \mathrm{AD}$. The decoction of the stem bark of Zanthoxylum liebmannianum decreased the count of intestinal nematode eggs in naturally infected sheep while the chloroform extract was found to be toxic to Ascaris suum. Alpha-sanshool from $Z$. liebmannianum was found to be the active compound. However, alpha-sanshool induced tonic-clonic seizures in mice and thus has some toxicity [161]. Thymol obtained from Thymus vulgaris is a monohydric phenol (methyl isopropyl phenol) and is used as vermicide in eliminating hookworms and Trichinella spi- ralis. Thymol is not active against Ascaris, Trichuris, and Enterobius. It is neurotoxic and affects kidneys. Pelletierin is an alkaloid obtained from the pomegranate tree, Punica granatum, and is active against Taenia sp. but causes headache, dizziness, nausea, vomiting, and diarrhea with colic pain; it is also known to be neurotoxic. Arecanut, the seed of Areca catechu is also known for its anthelmintic action; its active principle is arecoline, a colorless liquid. Dried flowers of Hagenia abyssnica, commonly called as "Kousso" or Cusso, are used against tapeworm (Taenia sp.) infections. Their active principle is identified as kosatxin. Palasonin derived from Butea frondosa and its piperavine salts were found to be active against $A$. lumbricoides [162]. Although these are not advantageous over existing synthetic anthelmintics (benzimidazole derivatives and ivermectin), they are effective in expelling the worms if used as a purgative. Interestingly, some plant anthelmintics directly inhibit the worms' motility due to cholinergic agonist/antagonist action as in the case of arecolin. However, the action of all these agents depends on several host factors too. 
Table 8 Plants with activity against helminths other than filariidae.

\begin{tabular}{|c|c|c|c|c|}
\hline Name of the plant & Family & Part/product used & Target parasite & Reference \\
\hline $\begin{array}{l}\text { Albizzia anthelmintica } \\
\text { A. lebbek }\end{array}$ & Mimosaceae & Bark & Hymenolepis diminuta & {$[167]$} \\
\hline Allium sativum & Liliaceae & Bulbs & Nematodes*, helminths & [173] \\
\hline Areca catechu & Arecaceae & Seed & Ascaria sp. & [135] \\
\hline Azadirachta indica & Meliaceae & Leaf & Helminthes* & [139] \\
\hline Bauhinia purpurea & Caesalpiniaceae & Leaf & Helminthes* & {$[174]$} \\
\hline Butea frondosa & Papilionaceae & Seed & A. lumbricoides in man, T. canis in dogs & {$[162,175]$} \\
\hline Camellia sinensis & Theaceae & Green tea & $\begin{array}{l}\text { Infective larvae of Teladorsagia } \\
\text { circumcincta and Trichostrongylus (in vitro) }\end{array}$ & {$[176]$} \\
\hline Carica papaya & Caricaceae & Seed, latex & Rat tapeworm, intestinal nematode & {$[168,177,178]$} \\
\hline Centratherum anthelminticum & Asteraceae & Seed & Tapeworm & [179] \\
\hline Chenopodium ambrosioides & Chenopodiaceae & Leaf, seed (oil of chenopodium) & Ascaris sp, hookworm & [173] \\
\hline Coriandrum sativum & Apiaceae & Crude extract of seed & Haemonchus contortus (in vitro and in vivo) & {$[172]$} \\
\hline Cucurbita maxima & Cucurbitaceae & Seed & Helminths* & {$[175,177,179]$} \\
\hline Cucurbita pepo & Cucurbitaceae & Seed & Hymenolepis nana, Dicrocoelium dendriticum & {$[175,177,179]$} \\
\hline Cyathocline purpurea & Asteraceae & Essential oil of aerial part & Tapeworm and hookworm & {$[177]$} \\
\hline Datura metel & Solonaceae & Fruit or flower & A. galli & [180] \\
\hline Delonix regia & Caesalpiniaceae & Flower & H. contortus & [179] \\
\hline Digenea simplex & Rhodophyceae & Kainic acid & Ascaris sp. & [135] \\
\hline Embelia schimperi & Myrsinaceae & Dried fruit & Hymenolepis diminuta (in vitro \& in vivo) & {$[165]$} \\
\hline Evolvulus alsinoides & Convolvulaceae & Crude extract & Helminths* & [180] \\
\hline Flemingia vestita & Fabaceae & Root, tuber-peel & Trematode, cestode, A. suum, A. lumbricoides & [99] \\
\hline Ficus glabrata, F. spp. & Moraceae & Latex & A. suum, Strongiloides, Trichuris, S. obvelata & {$[164,181]$} \\
\hline Limnophila repens & Scrophulariaceae & Oil & Helminths* & [175] \\
\hline Leucas caphalotes & Lamiaceae & Leaf & Helminths* & [174] \\
\hline Luffa echinata & Cucurbitaceae & Seed & Helminths* & {$[175]$} \\
\hline Mallotus philippinensis & Euphorbiaceae & Fruit (kamalin) & Diphyllobothrium latum & {$[175]$} \\
\hline Matteuccica orientalis & Onocleaceae & Root & Fasciola hepatica & [182] \\
\hline Millettia thonningii & Papilionaceae & Seed & Schistosoma mansoni & [183] \\
\hline Onobrychis viciifolia Scop. & Fabaceae & Plant (as forage) & H. contortus & [169] \\
\hline Piliostigma thoningii & Caesalpiniaceae & Bark & A. galli & {$[184]$} \\
\hline Polygonum glabrum & Polygonaceae & Leaf & Helminths* & {$[185]$} \\
\hline Psorelea corylifolia & Papilionaceae & Seed & Helminths* & {$[175]$} \\
\hline Quisqualis indica & Combretaceae & Quisqualic acid & Nematodes* & [177] \\
\hline Taverniera abyssinica & Leguminosae & Dried root & Nematodes* & [186] \\
\hline Urginea indica & Liliaceae & Bulb & A. suum & [187] \\
\hline Struthiola argentea & Thymelaeaceae & Plant & Helminth (in vitro) & {$[171]$} \\
\hline Teloxys graveolens (Willd.) & Chenopodiaceae & Plant & F. hepatica, A. galli & [170] \\
\hline Zanthoxylum liebmannianum & Rutaceae & Stem bark & Intestinal nematode of sheep, $A$. suum & {$[161]$} \\
\hline
\end{tabular}

* Parasite(s) not specified

The oil fractions from Limnophila conferta syn. L. repens Benth and L. heterophylla (Roxb) Benth syn. var. reflexa (Benth) Hook. f. belonging to Scrophulariaceae, and from Buddleja asiatica Lour (Buddeleia), B. neemda Ham. ex Roxb. syn. B. asiatica Lour. and B. globasa Hope belonging to the family Buddlejaceae were found to show good anthelmintic activity [163].

The latex of some species of Ficus (Moraceae) has been traditionally used as vermifuge in Central and South America. However, due to high acute toxicity (hemorrhagic enteritis), lateces are not recommended for use in traditional medicine [164]. Extract of the dried fruits/crushed seeds of Embelia schimperi Vatke, belonging to the family Myrsinaceae, is used by the Masai people of Tanzania and Kenya who believe that it eliminates adult Taenia saginata, the beef tapeworm. It was effective against tapeworms Hymenolepis diminuta in a rat model. No significant in vivo effect was observed against $H$. microstoma, the trematode Echinostoma caproni, and the nematode Heligmosomoides polygyrus in mice, although the worms could be killed in vitro. These results indicate that the crushed seeds of E. schimperi taken orally by the Masai people, indeed have an anthelmintic activity against human intestinal tapeworms [165]. The West African legume Millettia thonnigii is used in Ghana as an anthelmintic and as a purgative [166]. A chloroform extract of the seeds of Millettia thonningii which is known to be molluscicidal and cercaricidal was topically applied to mouse skin 2 and 24 hours prior to exposure to S. mansoni cercariae. The presence of $M$. thonningii extract components on the surface of the skin appeared to be effective in preventing subsequent establishment of infection. The compound responsible for the activity is thought to be the isoflavonoid alpinumisoflavone. The aqueous extract of Albizzia anthelmintica bark showed high anthelmintic activity (68-100\%) against experimental $H$. diminuta infection in albino rats; it was not toxic. The water extract from $A$. lebbek bark was less effective against the cestode and was toxic to rats at a high dose [167]. Papaya latex (Carica papaya) showed an antiparasitic efficacy against Heligmosomoides polygyrus in a mice model [168].

Sainfoin (Onobrychis viciifolia) extracts containing condensed tannins inhibited the migration of 3rd-stage larvae of Haemonchus contortus [169]. 5,7-Dihydroxyflavanone (pinocembrine) from the acetone extract of Teloxys graveolens (Willd.) Weber 
(Chenopodiaceae) exhibited fasciolicide, ovicide, and larvicide activities on newly excysted Fasciola hepatica, on infective eggs of A. galli, and on stage 3 larvae of Stomoxys calcitrans, respectively [170]. One of the flavones from Struthiola argentea (Thymelaeaceae) identified as 5,6,2',5',6'-pentamethoxy-3',4'methylenedioxyflavone, demonstrated the most potent anthelmintic activity with $90 \%$ inhibition of larval motility in vitro [171]. The crude aqueous and hydro-alcoholic extracts of the seeds of Coriandrum sativum (Apiaceae) inhibited hatching of eggs of $H$. contortus completely in a dose-dependent manner. The hydro-alcoholic extract showed better in vitro activity against adult parasites than the aqueous one [172].

\section{Conclusions and Prospects}

From times immemorial, the plant kingdom has been a veritable source of medicinal agents, and there are several success stories of plant derived drugs even in modern medicine. However, our efforts to discover plant products or develop new drugs on plant-based leads for the control and treatment of filariasis and other helminth infections have not been met with much success. In the last five decades, more than 100 plant products were reported to be beneficial in the treatment or control of these parasitic infections but they could not be developed into viable drugs for a variety of reasons. New animal models of human infection developed in recent years improved our understanding of host parasite interactions and provided us better models to identify anthelmintic/antifilarial activity of plant products. It is expected that the newer assay batteries coupled with quality controlled systematic plant identification, collection, storage, processing, etc., and the state-of-the-art technology of chemical "fingerprinting" of the products would help us build some success stories in the area of filariasis/helminth infections.

\section{Acknowledgements}

$\nabla$

The authors thank Dr. T.K. Chakraborty, Director, CDRI, Lucknow, for his encouragement and the CSIR for granting a Senior Research Fellowship (SKJ). This is CDRI communication no. 7970.

\section{References}

1 Harborne JB. Phytochemical methods. A guide to modern techniques of plant analysis, 3rd edition. London: Chapman \& Hall; 1998

2 Butler MS, Newman DJ. Mother Nature's gifts to diseases of man: the impact of natural products on anti-infective, anticholestemics and anticancer drug discovery. Prog Drug Res 2008; 65: 13-44

3 Kuhn T, Wang Y. Artemisinin - an innovative cornerstone for anti-malaria therapy. Prog Drug Res 2008; 66: 385-422

4 de Silva NR, Brooker S, Hotez PJ, Montresor A, Engels D, Savioli L. Soiltransmitted helminth infections: updating the global picture. Trends Parasitol 2003; 19: 547-551

5 Fincham JE, Markus MB, Adams VJ. Could control of soil-transmitted helminthic infection influence the HIV/AIDS pandemic. Acta Trop 2003; 86: 315-333

6 Molyneux D. Lymphatic filariasis (elephantiasis) elimination: a public health success and development opportunity. Filaria J 2003; 2: 13

7 WHO. The global burden of disease: 2004. Available at http://www. who.int/healthinfo/global_burden_disease/estimates_regional/en/index.html. Accessed October 10, 2010

8 Maizels RM, Gomez-Escobar N, Gregory WF, Murray J, Zang X. Immune evasion genes from filarial nematodes. Int J Parasitol 2001; 31: 889898
9 WHO. Onchocerciasis and its control. Report of a WHO Expert Committee on onchocerciasis control. World Health Organ Tech Rep Ser 1995; 852: $1-104$

10 Molyneux DH. Onchocerciasis control in West Africa: Current status and future of the onchocerciasis control programme. Parasitol Today 1995; 11: 399-402

11 WHO. Soil-transmitted helminthiasis. Number of children treated 2007-2008: update on the 2010 global target. Wkly Epidemiol Rec 2010; 85: 141-147

12 Stephenson LS, Latham MC, Kinoti SN, Kurz KM, Brigham H. Improvements in physical fitness of Kenyan schoolboys infected with hookworm, Trichuris trichiura and Ascaris lumbricoides following a single dose of albendazole. Trans R Soc Trop Med Hyg 1990; 84: 277-282

13 Nokes C, Grantham-McGregor SM, Sawyer AW, Cooper ES, Bundy DA. Parasitic helminth infection and cognitive function in school children. Proc Biol Sci 1992; 247: 77-81

14 Adams EJ, Stephenson LS, Latham MC, Kinoti SN. Physical activity and growth of Kenyan school children with hookworm, Trichuris trichiura and Ascaris lumbricoides infections are improved after treatment with albendazole. J Nutr 1994; 124: 1199-1206

15 Koroma MM, Williams RA, de la Haye RR, Hodges M. Effects of albendazole on growth of primary school children and the prevalence and intensity of soil-transmitted helminths in Sierra Leone. J Trop Pediatr 1996; 42: 371-372

16 Stoltzfus RJ, Albonico M, Chwaya HM, Savioli L, Tielsch J, Schulze K, Yip R. Hemoquant determination of hookworm-related blood loss and its role in iron deficiency in African children. Am J Trop Med Hyg 1996; 55: 399-404

17 Katiyar JC, Gupta S, Sharma S. Experimental models in drug development for helminthic diseases. Rev Infect Dis 1989; 11: 638-654

18 Murthy PK, Tyagi K, Roy Chowdhury TK, Sen AB. Susceptibility of Mastomys natalensis (GRA strain) to a subperiodic strain of human Brugia malayi. Indian J Med Res 1983; 77: 623-630

19 Murthy PK, Chowdhury TK, Sen AB. Indian cat (Felis indica) as a host to subperiodic Malaysian strain of human Brugia malayi. J Commun Dis 1983; 15: 100-105

20 Murthy PK, Srivastava AK, Joshi A, Sen AB, Murthy PSR, Ghatak S. Physiopathophysiology changes during infection in multimmate rats. I: Histological studies. IRCS Med Sci 1986; 14: 1106-1107

21 Tyagi K, Murthy PK, Chatterjee RK, Sen AB. Chemotherapeutic response of Brugia malayi to antifilarials in Mastomys natalensis. Indian J Parasitol 1986; 10: 195-207

22 Katiyar JC, Misra A, Gupta S, Visen PKS, Murthy PK, Sen AB. Efficacy of a substituted methyl benzimidazole carbamate against developing and adult helminth parasites. Vet Parasitol 1987; 23: 193-204

23 Murthy PK, Tyagi K, Sen AB. Attempt to infect Tatera indica with sub-periodic strain of Brugia malayi. Indian J Med Res 1987; 85: 471-472

24 Katiyar JC, Gupta S, Visen PK, Murthy PK, Misra A, Kumar S, Sarin JP. Methyl 5-[4-(2-pyridinyl)-1-piperazinylcarbonyl]-1H-benzimidazol2-yl carbamate: efficacy against developing and adult helminths by topical application. Indian J Exp Biol 1988; 26: 715-719

25 Murthy PK, Tyagi K, Chatterjee RK. Indian langur (Presbytis entellus) as experimental host for Brugia malayi infection. Curr Sci 1990; 59: 1236-1239

26 Murthy PK, Fatma N, Chatterjee RK. Comparative susceptibility of ivermectin against different filarial parasites. CSIR Golden Jubilee Symposium, Lucknow, India; 1992

27 Tyagi K, Murthy PK, Chatterjee RK. Brugia malayi in Indian leaf monkey (Presbytis entellus). Response to repeated exposures of infective larvae. Curr Sci 1996; 70: 164-167

28 Murthy PK, Chatterjee RK. Evaluation of two in vitro test systems employing Brugia malayi parasite for screening of potential antifilarials. Curr Sci 1999; 77: 1084-1089

29 Murthy PK, Khan MA, Rajani HB, Srivastava VML. Preadult stage of parasite is involved in the development of filarial limb edema in Brugia malayi-infected Indian leaf monkey (Presbytis entellus). Clin Diagn Lab Immunol 2002; 9: 913-918

30 Dube A, Murthy PK, Puri SK, Misra-Bhattacharya S. Presbytis entellus: a primate model for parasitic disease research. Trends Parasitol 2004; 20: $358-360$

31 Murthy PK, Srivastava K, Murthy PSR. Responses of Brugia malayi-Presbytis entellus, a non-human primate model of filariasis, to DEC, ivermectin and CDRI compound 82-437. Curr Sci 2004; 86: 101-108 
32 Sahare KN, Anandharaman V, Meshram VG, Meshram SU, Gajalakshmi D, Goswami K, Reddy MV. In vitro effect of four herbal plants on the motility of Brugia malayi microfilariae. Indian J Med Res 2008; 127: 467471

33 Lakshmi V, Joseph SK, Srivastava S, Verma SK, Sahoo MK, Dube V, Mishra SK, Murthy PK. Antifilarial activity in vitro and in vivo of some flavonoids tested against Brugia malayi. Acta Trop, advance online publication 6 July 2010; DOI: 10.1016/j.actatropica.2010.06.006

34 Townson S, Tagboto S, McGarry HF, Egerton GL, Taylor MJ. Onchocerca parasites and Wolbachia endosymbionts: evaluation of a spectrum of antibiotic types for activity against Onchocerca gutturosa in vitro. Filaria J 2006; 5: 4

35 Zahner H, Johri GN, Kohler P, Striebel HP, Franz M. In vitro effects of 2tert-butyl-benzothiazole derivatives on microfilariae of Litomosoides carinii, Brugia malayi and Acanthocheilonema viteae. Arzneimittelforschung 1991; 41: 764-768

36 Zaridah MZ, Idid SZ, Omar AW, Khozirah S. In vitro antifilarial effects of three plant species against adult worms of subperiodic Brugia malayi. J Ethnopharmacol 2001; 78: 79-84

37 Tippawangkosol P, Choochote W, Na-Bangchang K, Jitpakdi A, Pitasawat $B$, Riyong D. Comparative assessment of the in vitro sensitivity of Brugia malayi infective larvae to albendazole, diethylcarbamazine and ivermectin alone and in combination. Southeast Asian J Trop Med Public Health 2004; 35 (Suppl. 2): 15-21

38 Rao RU, Huang Y, Fischer K, Fischer PU, Weil GJ. Brugia malayi: Effects of nitazoxanide and tizoxanide on adult worms and microfilariae of filarial nematodes. Exp Parasitol 2009; 121: 38-45

39 Comley JC, Townson S, Rees MJ, Dobinson A. The further application of MTT-formazan colorimetry to studies on filarial worm viability. Trop Med Parasitol 1989; 40: 311-316

40 Rao UR, Salinas G, Mehta K, Klei TR. Identification and localization of glutathione S-transferase as a potential target enzyme in Brugia species. Parasitol Res 2000; 86: 908-915

41 Smith HL, Rajan TV. Tetracycline inhibits development of the infectivestage larvae of filarial nematodes in vitro. Exp Parasitol 2000; 95: 265270

42 Tiwari P, Tripathi LM, Raghu KG, Srivastava VM. Acanthocheilonema viteae: octopamine and its physiological role. Exp Parasitol 2004; 108: 53-58

43 Walter RD, Wittich RM, Kuhlow F. Filaricidal effect of mefloquine on adults and microfilariae of Brugia patei and Brugia malayi. Trop Med Parasitol 1987; 38: 55-56

44 Davies KP, Zahner H, Kohler P. Litomosoides carinii: mode of action in vitro of benzothiazole and amoscanate derivatives with antifilarial activity. Exp Parasitol 1989; 68: 382-391

45 Singhal KC, Saxena PN, Johri MB. Studies on the use of Setaria cervi for in vitro antifilarial screening. Jpn J Pharmacol 1973; 23: 793-797

46 Comley JC, Szopa TM, Strote G, Buttner M, Darge K, Buttner DW. A preliminary assessment of the feasibility of evaluating promising antifilarials in vitro against adult Onchocerca volvulus. Parasitology 1989; 99 (Pt. 3): 417-425

47 Townson S, Shay KE, Dobinson AR, Connelly C, Comley JC, Zea-Flores G. Onchocerca gutturosa and $O$. volvulus: studies on the viability and drug responses of cryopreserved adult worms in vitro. Trans R Soc Trop Med Hyg 1989; 83: 664-669

48 Comley JC. New macrofilaricidal leads from plants? Trop Med Parasitol 1990; 41: 1-9

49 Strote G, Darge K, Bonow I. Morphological alterations of male Onchocerca volvulus after in vitro exposure to mel w and milbemycin a confirming the results of viability tests. Trop Med Parasitol 1990; 41: 429-436

50 Cho-Ngwa F, Daggfeldt A, Titanji VP, Gronvik KO. Preparation and characterization of specific monoclonal antibodies for the detection of adult worm infections in onchocerciasis. Hybridoma (Larchmt) 2005; 24: $283-290$

51 Mukherjee M, Misra S, Chatterjee RK. Development of in vitro screening system for assessment of antifilarial activity of compounds. Acta Trop 1998; 70: 251-255

52 Singh DP, Misra S, Chatterjee RK. A new technique of in vitro assay of antifilarials using different life-forms of Acanthocheilonema viteae. Jpn J Exp Med 1990; 60: 303-309

53 Singh BK, Mishra M, Saxena N, Yadav GP, Maulik PR, Sahoo MK, Gaur RL, Murthy PK, Tripathi RP. Synthesis of 2-sulfanyl-6-methyl-1,4-dihydropyrimidines as a new class of antifilarial agents. Eur J Med Chem 2008; 43: 2717-2723
54 Nisha M, Kalyanasundaram M, Paily KP, Abidha, Vanamail P, Balaraman $K$. In vitro screening of medicinal plant extracts for macrofilaricidal activity. Parasitol Res 2007; 100: 575-579

55 Awasthi SK, Mishra N, Dixit SK, Singh A, Yadav M, Yadav SS, Rathaur S. Antifilarial activity of 1,3-diarylpropen-1-one: effect on glutathioneS-transferase, a phase II detoxification enzyme. Am J Trop Med Hyg 2009; 80: 764-768

56 Rao R, Well GJ. In vitro effects of antibiotics on Brugia malayi worm survival and reproduction. J Parasitol 2002; 88: 605-611

57 Gunawardena NK, Fujimaki Y, Aoki Y, Mishima N, Ezaki T, Uni S, Kimura $E$. Differential effects of diethylcarbamazine, tetracycline and the combination on Brugia pahangi adult females in vitro. Parasitol Int 2005; 54: $253-259$

58 Fujimaki Y, Kamachi T, Yanagi T, Caceres A, Maki J, Aoki Y. Macrofilaricidal and microfilaricidal effects of Neurolaena lobata, a Guatemalan medicinal plant, on Brugia pahangi. J Helminthol 2005; 79: 23-28

59 Batra S, Chatterjee RK, Srivastava VM. Antioxidant system of Litomosoides carinii and Setaria cervi: effect of a macrofilaricidal agent. Vet Parasitol 1992; 43: 93-103

60 Tyagi $K$, Murthy $P K$, Sen $A B$. Sequential changes in the antibody response of Mastomys natalensis consequent to Brugia malayi infection. Indian J Med Res 1985; 81: 269-274

61 Tyagi K, Murthy PK, Sen AB. Effect of some known antifilarials on the immune responses of Mastomys natalensis infected with Brugia malayi. Indian J Med Res 1986; 83: 155-161

62 Srivastava AK, Murthy PK, Joshi A, Sen AB, Murthy PSR, Ghatak S. Physiopathological changes during infection in multimammate rats. II. Enzyme studies. IRCS Med Sci 1986; 14: 1108-1109

63 Culbertson JT, Rose HM. Chemotherapy of filariasis in the cotton rat by administration of neostam. Science 1944; 99: 245

64 Tropical Disease Research-TDR. Seventh Programme Report. Chapter 4 Filariasis. Geneva: WHO; 1985: 1-20

65 Ash LR, Riley JM. Development of subperiodic Brugia malayi in the jird, Meriones unguiculatus, with notes on infections in other rodents. J Parasitol 1970; 56: 969-973

66 Murthy PK, Murthy PS, Tyagi K, Chatterjee RK. Fate of infective larvae of Brugia malayi in the peritoneal cavity of Mastomys natalensis and Meriones unguiculatus. Folia Parasitol (Praha) 1997; 44: 302-304

67 Petranyi G, Mieth H, Leitner I. Mastomys natalensis as an experimental host for Brugia malayi subperiodic. Southeast Asian J Trop Med Public Health 1975; 6: 328-337

68 Zahner H, Schares G. Experimental chemotherapy of filariasis: comparative evaluation of the efficacy of filaricidal compounds in Mastomys coucha infected with Litomosoides carinii, Acanthocheilonema viteae, Brugia malayi and B. pahangi. Acta Trop 1993; 52: 221-266

69 Mak JW, Navaratnam V, Ramachandran CP. Experimental chemotherapy of lymphatic filariasis. A review. Ann Trop Med Parasitol 1991; 85: $131-137$

70 Hewitt RI, Wallace WS, White E, Subbarow Y. Experimental chemotherapy of filariasis; experimental methods for testing drugs against naturally acquired filarial infections in cotton rats and dogs. J Lab Clin Med 1947: 32: 1293-1303

71 Sewell P, Hawking $F$. Chemotherapy of experimental filariasis. $\mathrm{Br}$ J Pharmacol Chemother 1950; 5: 239-260

72 Chatterjee RK, Fatma N, Agarwal VK, Sharma S, Anand N. Comparative antifilarial efficacy of the $\mathrm{N}$-oxides of diethylcarbamazine and two of its analogues. Trop Med Parasitol 1989; 40: 474-475

73 Fatma N, Sharma S, Chatterjee RK. 2,2'-Dicarbomethoxyamino-5,5'-dibenzimidazolyl ketone - a new antifilarial agent. Acta Trop 1989; 46: 311-321

74 Srivastava SK, Chauhan PM, Bhaduri AP, Murthy PK, Chatterjee RK. Secondary amines as new pharmacophores for macrofilaricidal drug design. Bioorg Med Chem Lett 2000; 10: 313-314

75 Stables JN, Lees GM, Rankin R. The potential of mice as animal models for antifilarial screening. Trop Med Parasitol 1988; 39: 25-28

76 Singh DP, Rathore S, Misra S, Chatterjee RK, Ghatak S, Sen AB. Studies on the causation of adverse reactions in microfilaraemic host following diethylcarbamazine therapy (Dipetalonema viteae in Mastomys natalensis). Trop Med Parasitol 1985; 36: 21-24

77 Kinnamon KE, Klayman DL, Poon BT, McCall JW, Dzimianski MT, Rowan $S J$. Filariasis testing in a jird model: new drug leads from some old standbys. Am J Trop Med Hyg 1994; 51: 791-796 
78 Kinnamon KE, Engle RR, Poon BT, Ellis WY, McCall JW, Dzimianski MT. Anticancer agents suppressive for adult parasites of filariasis in Mongolian jirds. Proc Soc Exp Biol Med 2000; 224: 45-49

79 Fujimaki Y, Sithithaworn P, Mitsui Y, Aoki Y. Delayed macrofilaricidal activity of diethylcarbamazine against Brugia pahangi in Mongolian jirds. J Helminthol 2004; 78: 293-295

80 Lammler G, Herzog H, Gruner D. Development of chemotherapeutic agents of parasitic diseases. Amsterdam: North Holland Publishing Company; 1975: 157

81 Sadanaga A, Hayashi Y, Tanaka H, Nogami S, Shirasaka A. Evaluation of the transplantation method of adult Brugia malayi into the jird, Meriones unguiculatus, for testing macrofilaricides. Jpn J Exp Med 1984; 54: 275-277

82 Gaur RL, Dixit S, Sahoo MK, Khanna M, Singh S, Murthy PK. Anti-filarial activity of novel formulations of albendazole against experimental brugian filariasis. Parasitology 2007; 134: 537-544

83 Tiwari VK, Tewari N, Katiyar D, Tripathi RP, Arora K, Gupta S, Ahmad R, Srivastava AK, Khan MA, Murthy PK, Walter RD. Synthesis and antifilarial evaluation of N1,Nn-xylofuranosylated diaminoalkanes. Bioorg Med Chem 2003; 11: 1789-1800

84 Mak JW, Lam PL, Rain AN, Suresh K. Effect of ivermectin against subperiodic Brugia malayi infection in the leaf monkey, Presbytis cristata. Parasitol Res 1988; 74: 383-385

85 Mak JW, Lam PL, Choong MF, Suresh K. Antifilarial activity of intravenous suramin and oral diethylcarbamazine citrate on subperiodic Brugia malayi in the leaf-monkey, Presbytis cristata. J Helminthol 1990; 64: 96-99

86 Murthy PK, Tyagi K, Sen AB. Susceptibility of Macaca mulatta to a subperiodic strain of Brugia malayi. Indian J Parasitol 1986; 10: 189-192

87 Misra S, Tyagi K, Chatterjee RK. Experimental transmission of nocturnally periodic Wuchereria bancrofti to Indian leaf monkey (Presbytis entellus). Exp Parasitol 1997; 86: 155-157

88 Schacher JF. Laboratory models in filariasis: a review of filarial lifecycle patterns. Southeast Asian J Trop Med Public Health 1973; 4: 336-349

89 Huber W, Koella JC. A comparison of three methods of estimating EC50 in studies of drug resistance of malaria parasites. Acta Trop 1993; 55: 257-261

90 Page C, Page M, Noel C. A new fluorimetric assay for cytotoxicity measurements in vitro. Int J Oncol 1993; 3: 473-476

91 Mosmann T. Rapid colorimetric assay for cellular growth and survival: application to proliferation and cytotoxicity assays. J Immunol Methods 1983; 65: 55-63

92 Duwel D. Laboratory methods in the screening of anthelmintics. Prog Drug Res 1975; 19: 48-63

93 Colgrave ML, Kotze AC, Kopp S, McCarthy JS, Coleman GT, Craik DJ. Anthelmintic activity of cyclotides: In vitro studies with canine and human hookworms. Acta Trop 2009; 109: 163-166

94 Hounzangbe-Adote S, Fouraste I, Moutairou K, Hoste H. In vitro effects of four tropical plants on the activity and development of the parasitic nematode, Trichostrongylus colubriformis. J Helminthol 2005; 79: 2933

95 Bizimenyera ES, Githiori JB, Eloff JN, Swan GE. In vitro activity of Peltophorum africanum Sond. (Fabaceae) extracts on the egg hatching and larval development of the parasitic nematode Trichostrongylus colubriformis. Vet Parasitol 2006; 142: 336-343

96 Alonso-Diaz MA, Torres-Acosta JF, Sandoval-Castro CA, Capetillo-Leal C, Brunet $S$, Hoste $H$. Effects of four tropical tanniniferous plant extracts on the inhibition of larval migration and the exsheathment process of Trichostrongylus colubriformis infective stage. Vet Parasitol 2008; 153: 187-192

97 Alonso-Diaz MA, Torres-Acosta JF, Sandoval-Castro CA, Aguilar-Caballero $A J$, Hoste $H$. In vitro larval migration and kinetics of exsheathment of Haemonchus contortus larvae exposed to four tropical tanniniferous plant extracts. Vet Parasitol 2008; 153: 313-319

98 Maphosa V, Masika PJ, Bizimenyera ES, Eloff JN. In-vitro anthelminthic activity of crude aqueous extracts of Aloe ferox, Leonotis leonurus and Elephantorrhiza elephantina against Haemonchus contortus. Trop Anim Health Prod 2010; 42: 301-307

99 Tandon V, Pal P, Roy B, Rao HS, Reddy KS. In vitro anthelmintic activity of root-tuber extract of Flemingia vestita, an indigenous plant in Shillong, India. Parasitol Res 1997; 83: 492-498
100 Marquez-Navarro A, Nogueda-Torres B, Hernandez-Campos A, SoriaArteche O, Castillo R, Rodriguez-Morales S, Yepez-Mulia L, HernandezLuis $F$. Anthelmintic activity of benzimidazole derivatives against Toxocara canis second-stage larvae and Hymenolepis nana adults. Acta Trop 2009; 109: 232-235

101 Keiser J. In vitro and in vivo trematode models for chemotherapeutic studies. Parasitology 2010; 137: 589-603

102 Xue J, Xiao SH, Xu LL, Qiang $H Q$. The effect of tribendimidine and its metabolites against Necator americanus in golden hamsters and Nippostrongylus braziliensis in rats. Parasitol Res 2010; 106: 775-781

103 Albonico M, Allen H, Chitsulo L, Engels D, Gabrielli AF, Savioli L. Controlling soil-transmitted helminthiasis in pre-school-age children through preventive chemotherapy. PLoS Negl Trop Dis 2008; 2: e126

104 Boray JC, Happich FA, Andrews JC. Studies on the suitability of the albino rat for testing anthelminthic activity against Fasciola hepatica. Ann Trop Med Parasitol 1967; 61: 104-111

105 Campbell WC, Fisher MH, Stapley EO, Albers-Schonberg G, Jacob TA. Ivermectin: a potent new antiparasitic agent. Science 1983; 221: 823-828

106 Behm CA, Bendig MM, McCarter JP, Sluder AE. RNAi-based discovery and validation of new drug targets in filarial nematodes. Trends Parasitol 2005; 21: 97-100

107 Chatterjee RK, Fatma N, Murthy PK, Sinha P, Kulshreshtha DK, Dhawan $B N$. Macrofilaricidal activity of the stem bark of Streblus asper and its major active constituents. Drug Dev Res 1992; 26: 67-78

108 Misra N, Sharma M, Raj K, Dangi A, Srivastava S, Misra-Bhattacharya S. Chemical constituents and antifilarial activity of Lantana camara against human lymphatic filariid Brugia malayi and rodent filariid Acanthocheilonema viteae maintained in rodent hosts. Parasitol Res 2007; 100: 439-448

109 Dalziel JM. The useful plants of west tropical Africa. London: The Crown Agents for the Colonies; 1937: 612

110 Burkill HM. The useful plants of west tropical Africa, 2nd edition. Kew: Royal Botanic Gardens; 1985: 960

111 Kiuchi F, Miyashita N, Tsuda Y, Kondo K, Yoshimura H. Studies on crude drugs effective on visceral larva migrans. I. Identification of larvicidal principles in betel nuts. Chem Pharm Bull (Tokyo) 1987; 35: 28802886

112 Murthy PK. Anthelmintics from medicinal plants. In: Sood ML, editor Helminthology in India. India: International Book Distributors; 2003 377-392

113 Singh NP, Singh VK. Streblus asper Lour. - An ancient Indian drug for the cure of filariasis. Acta Bot Indica 1987; 15: 108-109

114 Singh NP, Ram ER. Filaria and its herbal cure. New Botanist 1988; 15 : 201-205

115 Kilian HD. Preliminary data on the effects of an extract from Cassia aubrevellei in onchocerciasis. Hamburg: Liberia Research Unit of the Tropical Institute; 1987: 33-34

116 Kilian HD, John K, Buttner DW, Kraus L. In vivo and in vitro effects of extracts of Cassia aubrevillei in onchocerciasis. O-NOW Symposium on Onchocerciasis, Leiden, Netherlands; 1989

117 Titanji VPK, Evehe MS, Ayafor JF, Kimbu SF. Novel Onchocerca volvulus filarcides from Carapa procera, Polyalthia suaveolens and Pachypodanthium staudii. O-NOW Symposium on Onchocerciasis, Leiden, Netherlands; 1989

118 Suresh M, Kaleysa Raj R. Cardol: The antifilarial principle from Anacardium occidentale. Curr Sci 1990; 59: 477-479

119 Kulangara AC, Subramanian R. Preliminary studies on the effects of certain compounds on the filarial worm of the lizard, including an estimate of the toxicity of sodium flouride. Indian J Med Res 1960; 48: 698-704

120 Dutta A, Sukul NC. Filaricidal properties of a wild herb, Andrographis paniculata. J Helminthol 1982; 56: 81-84

121 Datta A, Sukul NC. Antifilarial effect of Zingiber officinale on Dirofilaria immitis. J Helminthol 1987; 61: 268-270

122 Titanji VPK, Ayafor JF, Mulufi JP, Mbacham WF. In vitro killing of Onchocerca volvulus (Filaroidea) adults and microfilariae by selected Cameroonian medicinal plant extracts. Fitoterpia 1987; 58: 338-339

123 Parveen N, Singhal KC, Khan NU. Screening of some plant extracts for their potential antifilarial activity using Setaria cervi as test organism. International Conference on Recent Advances in Medicinal, Aromatic and Spice Crops, New Delhi, India; 1989 
124 Singh $R$, Singhal KC, Khan NU. Antifilarial activity of the leaves of Mallotus philippensis Lam. on Setaria cervi (Nematode Filarioidea) in vitro. Indian J Physiol Pharmacol 1997; 41: 397-403

125 Ampofo 0. "Plants that heal" World Health. The Magazine of the World Health Organization 1977: 26-30

126 Khunkitti W, Fujimaki Y, Aoki Y. In vitro antifilarial activity of extracts of the medicinal plant Cardiospermum halicacabum against Brugia pahangi. J Helminthol 2000; 74: 241-246

127 Sahare KN, Anandhraman V, Meshram VG, Meshram SU, Reddy MV, Tumane PM, Goswami K. Anti-microfilarial activity of methanolic extract of Vitex negundo and Aegle marmelos and their phytochemical analysis. Indian J Exp Biol 2008; 46: 128-131

128 Lakshmi V, Saxena A, Pandey K, Bajpai P, Misra-Bhattacharya S. Antifilarial activity of Zoanthus species (Phylum Coelenterata, Class Anthzoa) against human lymphatic filaria, Brugia malayi. Parasitol Res 2004; 93: 268-273

129 Mathew N, Misra-Bhattacharya S, Perumal V, Muthuswamy K. Antifilarial lead molecules isolated from Trachyspermum ammi. Molecules 2008; 13: 2156-2168

130 Gaur RL, Sahoo MK, Dixit S, Fatma N, Rastogi S, Kulshreshtha DK, Chatterjee RK, Murthy PK. Antifilarial activity of Caesalpinia bonducella against experimental filarial infections. Indian J Med Res 2008; 128 : 65-70

131 Haerdi F. Die Eingeborenen-Heilpflanzen des Ulanga-Distriktes Tanganjikas (Ostafrika). Acta Trop Suppl 8 1964: 1-278

132 Oguakwa JU, Galeffi C, Messana I, Patamia M, Nicoletti M, Marini-Bettolo GB. Research on African medicinal plants. III New alkaloids from Alstonia boonei De Wild Gazzetta. Chim Ital 1983; 113: 533-535

133 Oliver-Bever BEP. Anti-infective activity of higher plants. Medicinal plants in Tropical West Africa. Cambridge: Cambridge University Press; 1986: 123-190

134 Ojewole JAO. Studies on the pharmacology of echitamine, an alkaloid from the stem bark of Alstonia booneri L. (Apocynaceae). Int J Crude Drugs Res 1984; 22: 121-143

135 Farnsworth NR, Akerele O, Bingel AS, Soejarto DD, Guo Z. Medicinal plants in therapy. Bull World Health Organ 1985; 63: 965-981

136 Guha Bakshi DN, Sensarma P, Pal DC. A lexicon of medicinal plants in India. Calcutta: Naya Prokash; 1999: 290

137 Watt JMM, Breyer-Brandwijk G. The medicinal and poisonous plants of Southern and Eastern Africa, 2nd edition. London: E. \& S. Livingstone, Ltd.; 1962

138 Githens TS. Drug plants of Africa, African handbooks No. 8. Philadelphia: University of Pennsylvania Press; 1948: 125

139 Satyavati GV, Gupta AK, Tandon N. Medicinal plants of India. New Delhi, India: Indian Council of Medical Research; 1986

140 Banu MJ, Nellaiappan K, Dhandayuthapani S. Mitochondrial malate dehydrogenase and malic enzyme of a filarial worm Setaria digitata: some properties and effects of drugs and herbal extracts. Jpn J Med Sci Biol 1992; 45: 137-150

141 Ayensu ES. Medicinal plants of West Africa. Algonac, Michigan: Reference Publications Inc.; 1978: 330

142 Deka L, Majumdar R, Dutta AM. Some Ayurvedic important plants from district Karnrup (Assam). Ancient Sci Life 1983; 3: 108-115

143 Al-Yahya MA, Al-Meshal IA, Mossa JS, Tariq M. Phytochemical and pharmacological studies on Calotropis procera. 3rd International Conference of Traditional and Folk Medicine, Lecatecas, Mexico; 1985

144 Al-Yahya MA. Phytochemical studies on the plants used in traditional medicine of Saudi Arabia. Fitoterapia 1986; 47: 179-182

145 Sahu TR. Less known uses of weeds as medicinal plants. Ancient Sci Life 1984; 4: 245-249

146 Hedberg I, Hedberg O, Madati PJ, Mshigeni KE, Mshiu EN, Samuelsson G. Inventory of plants used in traditional medicine in Tanzania. II. Plants of the families Dilleniaceae - Opiliaceae. J Ethnopharmacol 1983; 9: 105-127

147 Iwu MM. Empirical investigation of dietary plants used in Igbo Ethnomedicine. New York: Nina Etkined Redgroove Publishing Company; 1986: 116

148 Hedberg I, Hedberg O, Madati PJ, Mshigeni KE, Mshiu EN, Samuelsson G. Inventory of plants used in traditional medicine in Tanzania. Part III. Plants of the families Papilionaceae-Vitaceae. J Ethnopharmacol 1983; 9: 237-260

149 Maheshwari JK, Singh KK, Saba S. Ethno-medicinal uses of plants by the Thurus of Kheri District, U.P. Bull Med Ethnobot Res 1980; 1: 318-337
150 Whistler WA. Traditional and herbal medicine in the Cook Islands. J Ethnopharmacol 1985; 13: 239-280

151 Baoua M, Fayn J, Bassiere J. Preliminary phytochemical testing of some medical plants of Niger. Planta Med 1976; 10: 251-266

152 Dragendorff G. Die Heilpflanzen der verschiedenen Völker und Zeiten. Stuttgart: Ferdinand Enke; 1898

153 Lewis WH, Manony PFE. Medical botany: plants affecting man's health. New York: John Wiley and Sons; 1977: 240

154 Vasileva B. Plantes mediques Conakryinales de Guinea. Republic de Guinea: Conakry; 1969

155 Kokward JO. Medicinal plants of East Africa. Nairobi, Kenya: East Africa Literature Bureau; 1976

156 Kerharo J, Adam JG. Pharmacopée sénégalaise traditionelle. Paris: Vigot; 1974

157 Parveen N, Singhal KC, Khan NU, Singhal P. Potential antifilarial activity of Streblus asper against Setaria cervi (Nematoda: Filaroidea). Indian J Pharmacol 1989; 21: 16-21

158 Kliks MM. Studies on the traditional herb anthelmintic Chenopodium ambrosoides L. Ethnopharmacological evaluation and clinical field trials. Soc Sci Med 1985; 21: 879-886

159 Ibrahim MA, Nwude N, Ogunsui RA, Aliu YO. Screening of West African plants for anthelmintic activity. ILCA Bull 1984; 17: 19-23

160 Takki S. Anthelminitic effect of fern preparations and their action on some liver function tests in man. Ann Med Exp Fenn 1967; 45: 341 351

161 Navarrete A, Hong E. Anthelmintic properties of alpha-sanshool from Zanthoxylum liebmannianum. Planta Med 1996; 62: 250-251

162 Raj RK, Kurup PA. Anthelmintic activity, toxicity and other pharmacological properties of palasonin, the active principle of Butea frondosa seeds and its piperazine salt. Indian J Med Res 1968; 56: 1818-1825

163 Rastogi RP, Mehrotra BN. Compendium of Indian medicinal plants. New Delhi: CDRI/CSIR/PID; 1995: 125, 435

164 de Amorin A, Borba HR, Carauta JP, Lopes D, Kaplan MA. Anthelmintic activity of the latex of Ficus species. J Ethnopharmacol 1999; 64: 255258

165 Bogh HO, Andreassen J, Lemmich J. Anthelmintic usage of extracts of Embelia schimperi from Tanzania. J Ethnopharmacol 1996; 50: 35-42

166 Perrett S, Whitfield PJ, Sanderson L, Bartlett A. The plant molluscicide Millettia thonningii (Leguminosae) as a topical antischistosomal agent. J Ethnopharmacol 1995; 47: 49-54

167 Galal M, Bashir AK, Salih AM, Adam SE. Activity of water extracts of Albizzia anthelmintica and $A$. lebbek barks against experimental Hymenolepis diminuta infection in rats. J Ethnopharmacol 1991; 31: 333337

168 Satrija F, Nansen P, Murtini S, He S. Anthelmintic activity of papaya latex against patent Heligmosomoides polygyrus infections in mice. J Ethnopharmacol 1995; 48: 161-164

169 Barrau E, Fabre N, Fouraste I, Hoste H. Effect of bioactive compounds from Sainfoin (Onobrychis viciifolia Scop.) on the in vitro larval migration of Haemonchus contortus: role of tannins and flavonol glycosides. Parasitology 2005; 131: 531-538

170 Del Rayo Camacho M, Sanchez B, Quiroz H, Contreras JL, Mata R. Pinocembrine: a bioactive flavanone from Teloxys graveolens. J Ethnopharmacol 1991; 31: 383-389

171 Ayers S, Zink DL, Mohn K, Powell JS, Brown CM, Murphy T, Brand R, Pretorius $S$, Stevenson D, Thompson D, Singh SB. Flavones from Struthiola argentea with anthelmintic activity in vitro. Phytochemistry 2008; 69: 541-545

172 Eguale T, Tilahun G, Debella A, Feleke A, Makonnen E. In vitro and in vivo anthelmintic activity of crude extracts of Coriandrum sativum against Haemonchus contortus. J Ethnopharmacol 2007; 110: 428433

173 Booth S, Johns T, Lopez-Palacios CY. Factors influencing self-diagnosis and treatment of perceived helminthic infection in a rural Guatemalan community. Soc Sci Med 1993; 37: 531-539

174 Jain SK, Sinha BK, Saklani A. Some interesting medicinal plants known among several tribes of India. Ethnobotany 1989; 1: 89-100

175 Rastogi RP, Mehrotra BN. Compendium of Indian medicinal plants. New Delhi: CDRI/CSIR/PID; 1990

176 Molan AL, Sivakumaran S, Spencer PA, Meagher LP. Green tea flavan-3ols and oligomeric proanthocyanidins inhibit the motility of infective larvae of Teladorsagia circumcincta and Trichostrongylus colubriformis in vitro. Res Vet Sci 2004; 77: 239-243

177 Rastogi RP, Mehrotra BN. Compendium of Indian medicinal plants. New Delhi: CDRI/CSIR/PID; 1993 
178 Satrija F, Nansen P, Bjorn H, Murtini S, He S. Effect of papaya latex against Ascaris suum in naturally infected pigs. J Helminthol 1994; 68: 343-346

179 Rastogi RP, Mehrotra BN. Compendium of Indian medicinal plants. New Delhi: CDRI/CSIR/PID; 1991

180 Dhar ML, Dhar MM, Dhawan BN, Mehrotra BN, Ray C. Screening of Indian plants for biological activity. Indian J Exp Biol 1968; 6: 232-247

181 Hansson A, Veliz G, Naquira C, Amren M, Arroyo M, Arevalo G. Preclinical and clinical studies with latex from Ficus glabrata HBK, a traditional intestinal anthelminthic in the Amazonian area. J Ethnopharmacol 1986; 17: 105-138

182 Shiramizu K, Tuchida T, Aru M. Anthelmintic effect of cude preparation containing the root of Matteuccia orientalis on bovine fasciolosis. J Jpn Vet Med Assoc 1993; 46: 561-564
183 Perrett S, Whitfield PJ, Bartlett A, Sanderson L. Attenuation of Schistosoma mansoni cercariae with a molluscicide derived from Millettia thonningii. Parasitology 1994; 109 (Pt. 5): 559-563

184 Asuzu IU, Onu UO. Anthelmintic activity of the ethanolic extract of Piliostigma thonningii bark in Ascaridia galli infected chickens. Fitoterapia 1994; 65: 291-297

185 Muddathir AK, Balansard G, Timon-David P, Babadjamian A, Yogoub AK, Julien MJ. Anthelmintic properties of Polygonum glabrum. J Pharm Pharmacol 1987; 39: 296-300

186 Stadler M, Dagne E, Anke H. Nematicidal activities of two phytoalexins from Taverniera abyssinica. Planta Med 1994; 60: 550-552

187 Aye T, Mya B, Saw H, Tin M, Marlar L, Po Aung S. Screening of some medicinal plants reputed for anthelminthic activity on in vitro test models. Myanmar Health Sci Res J 1993; 5: 79-84 